\title{
RAIMAR WeBER
}

\section{Estudo da associação entre antígenos de histocompatibilidade leucocitária (HLA) e}

pênfigo vulgar em pacientes brasileiros

Tese apresentada à Faculdade de Medicina da Universidade de São Paulo para obtenção do Título de Doutor em Ciências

Programa de Otorrinolaringologia

Orientador: Prof. Dr. Ivan Dieb Miziara

São Paulo 
Dados Internacionais de Catalogação na Publicação (CIP)

Preparada pela Biblioteca da

Faculdade de Medicina da Universidade de São Paulo

Creprodução autorizada pelo autor

Weber, Raimar

Estudo da associação entre antígenos de histocompatibilidade leucocitária (HLA) e pênfigo vulgar em pacientes brasileiros / Raimar Weber. -- São Paulo, 2010.

Tese(doutorado)--Faculdade de Medicina da Universidade de São Paulo.

Programa de Otorrinolaringologia.

Orientador: Ivan Dieb Miziara.

Descritores: 1.Pênfigo vulgar 2.Antígenos HLA 3.Antígenos HLA-DR 4.Antígenos HLA-A 5.Antígenos HLA-B 6.Genes classe I do complexo de histocompatibilidade (MHC) 7.Genes classe II do complexo de histocompatibilidade (MHC)

USP/FM/DBD-390/10 


\section{Dedicatória}

A meus pais, Elmo e Léa.

Netos de imigrantes, nascidos em meio a poucos recursos;

superaram as dificuldades e me possibilitaram oportunidades das quais não puderam desfrutar. Esta obra também é resultado do esforço de vocês. 


\section{Agradecimentos}

A todos aqueles que, de uma forma ou de outra, auxiliaram e contribuíram com a realização deste trabalho, com minha formação médica ou com a construção do meu caráter e da minha personalidade.

\section{Agradecimento especial}

Aos pacientes que participaram deste estudo. Anônimos, literalmente "deram o sangue" sem receber em troca nada além da satisfação de estarem contribuindo com o conhecimento científico. Têm nosso respeito, nossa gratidão e nossa admiração.

À minha amada esposa Mariana Guedes, pelo apoio, pelo carinho, pela cumplicidade e por tornar feliz cada um de nossos dias.

Ao meu orientador, professor Dr. Ivan Dieb Miziara, pela oportunidade oferecida, pelos valiosos conhecimentos transmitidos e pela confiança depositada. Espero que possamos continuar juntos dando seguimento às pesquisas na área de estomatologia.

Ao Dr. Ricardo Ferreira Bento, professor titular de Otorrinolaringologia da USP, ao Dr. Helcio Rodrigues e ao Prof. Dr. Jorge Kalil, do laboratório de Imunologia de Transplantes do INCOR, por permitirem e viabilizarem a realização deste estudo em vossos departamentos. 
Ao Dr. Niels Salles Willo Wilhelmsen por, além de auxiliar no recrutamento dos pacientes, ter ensinado as técnicas de extração de DNA e firmado o vínculo com o laboratório de Imunologia de Transplantes.

A Germano Prehus Filho, Carlos Viggiani, Claudia Savioli, Mário D'Angelo Jr., Celia Yamaguti e demais integrantes do laboratório de Imunologia de Transplantes pela indispensável participação em todas as etapas de extração e tipificação de DNA.

Ao Dr. Francisco Monteiro pela ajuda na confecção do artigo e aos Prof. Drs. Rui Imamura, João Ferreira de Mello Junior, Domingos Hiroshi Tsuji e Luiz Ubirajara Sennes pelas críticas e observações realizadas durante o exame de qualificação.

À Coordenação de Aperfeiçoamento de Pessoal de Nível Superior (CAPES) pela bolsa de estudos cedida.

Às Sras. Maria Marilede e Maria Márcia Alves pela valiosa ajuda em todas etapas do processo burocrático.

Aos professores José Morales, Elvino Barros, Francisco Veronese, Fernando Thomé, Celso Dall'Igna e Sady Selaimen da Costa por terem despertado meu interesse na pesquisa científica ainda durante o curso de Medicina. 
"Aprender é a única coisa da qual a mente nunca se cansa, nunca tem medo e nunca se arrepende"

Leonardo da Vinci 
Esta tese está de acordo com as seguintes normas, em vigor no momento desta publicação:

Referências: adaptado de International Committee of Medical Journals Editors (Vancouver).

Universidade de São Paulo. Faculdade de Medicina. Serviço de Biblioteca e Documentação. Guia de apresentação de dissertações, teses e monografias. Elaborado por Annelise Carneiro da Cunha, Maria Julia de A. L. Freddi, Maria F. Crestana, Marinalva de Souza Aragão, Suely Campos Cardoso, Valéria Vilhena. $2^{a}$ ed. São Paulo: Serviço de Biblioteca de Documentação; 2005.

Abreviaturas dos títulos dos periódicos de acordo com List of Journals Indexed in Index Medicus. 


\section{Sumário}

Lista de abreviaturas, símbolos e siglas

Lista de Tabelas

Lista de Figuras

Resumo

Summary

1. Introdução ........................................................ 1

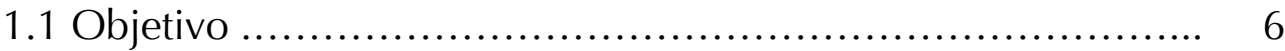

2. Revisão da Literatura .................................................... 7

2.1 A Biologia do Epitélio e os Desmossomos .................... 7

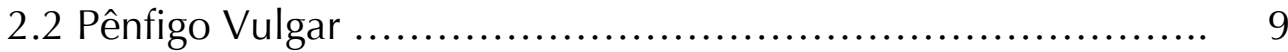

2.2.1 Epidemiologia ....................................... 9

2.2.2 Aspectos clínicos ............................... 10

2.2.3 Diagnóstico ....................................... 13

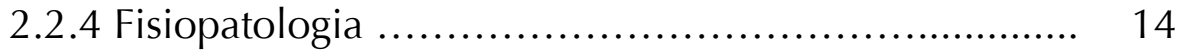

2.2.4.1 Autoanticorpos Anti-Desmossomos .......... 14

2.2.4.2 Imunidade Celular .......................... 15

2.2.5 Evidências de Participação Genética ..................... 16

2.3 O Complexo Principal de Histocompatibilidade e o Sistema de Antígeno Leucocitário Humano ................... 18

2.3.1 Genes do Sistema HLA Classes I e II e Nomenclatura . 18

2.3.2 Mecanismo de Apresenção de Antígenos ............... 21

2.4 Importância da identificação dos alelos associados ao PV ...... 22

2.5 Base Estrutural para Susceptibilidade ao Pênfigo Vulgar de Portadores do Alelo HLA DRB1 *04:02 ...................... 23

2.6 Associação entre outros Alelos HLA e Pênfigo Vulgar .......... 24

2.7 Particularidades da Formação da População Brasileira ......... 27 
3. Casuística e Método .................................................. 29

3.1 Casuística ................................................ 29

3.1.1 Grupo de Pacientes com Pênfigo Vulgar .............. 29

3.1.2 Grupo Controle .................................. 31

3.2 Método ................................................... 32

3.2.1 Avaliação clínica e coleta de sangue periférico ........ 32

3.2.2 Extração e Tipificação do DNA ....................... 33

3.2.3 Análise estatística ................................... 35

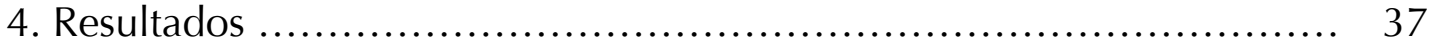

5. Discussão .......................................................... 58

5.1 Desenho do estudo e composição dos grupos caso e controle .. 60

5.2 Associações entre os alelos do sistema HLA e PV ............... 66

6. Conclusões ......................................................... 76

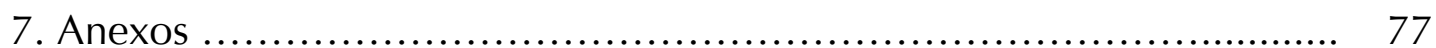

Anexo A - Equilíbrio Hardy-Weinberg e Desequilíbrio de Ligação . 77

Anexo B - Termo de aprovação do Comitê de Ética (CaPPesq) ..... 80

Anexo C - Termo de Consentimento Livre e Esclarecido ............ 81

Anexo D - Protocolo de avaliação de sinais e sintomas clínicos ... 85

Anexo E - Resultados do Equilíbrio de Hardy-Weinberg ............ 86

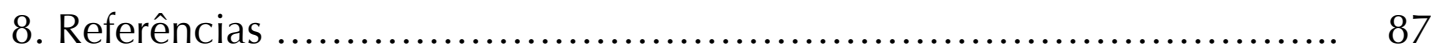




\section{Lista de abreviaturas, siglas e símbolos}

\begin{tabular}{|c|c|}
\hline / & dividido \\
\hline$\%$ & porcento \\
\hline \pm & mais ou menos \\
\hline$x$ & vezes \\
\hline$<$ & menor que \\
\hline$=$ & igual a \\
\hline$>$ & maior que \\
\hline$\geq$ & maior ou igual a \\
\hline${ }^{\circ} \mathrm{C}$ & Graus Celsius \\
\hline $\mathrm{C} 3$ & Fração C3 do complemento \\
\hline CAPPesq & Comissão de Avaliação de Projetos de Pesquisa \\
\hline DNA & Deoxyribonucleic acid (ácido desoxirribonucleico) \\
\hline Dsg & Desmogleína \\
\hline EDTA & $\begin{array}{l}\text { Ethylenediamine tetraacetic acid (ácido etilenodiamino tetra- } \\
\text { acético) }\end{array}$ \\
\hline EHW & Equilíbrio de Hardy-Weinberg \\
\hline ELISA & Enzime-Linked Immunosorbent Assay \\
\hline EUA & Estados Unidos da América \\
\hline FDR & False Discovery Rate (Taxa de descobertas falsas) \\
\hline HLA & Human Leukocyte Antigen (Antígeno Leucocitário Humano) \\
\hline IBGE & Instituto Brasileiro de Geografia e Estatística \\
\hline IC95\% & Intervalo de confiança de 95 porcento \\
\hline IFD & Imunofluorescência Direta \\
\hline IFI & Imunofluorescência Indireta \\
\hline $\lg G$ & Imunoglobulina G \\
\hline INCOR & Instituto do Coração \\
\hline kD & kiloDalton \\
\hline LT & Linfócitos T \\
\hline
\end{tabular}


MHC Major Histocompatibility Complex (Complexo Principal de Histocompatibilidade)

$\mathrm{mL} \quad$ mililitro

$\mathrm{mM}$ milimolar

nm nanômetro

NMDP National Marrow Donor Program (Programa nacional de doadores de medula)

PCR Polymerase chain reaction (reação em cadeia da polimerase)

PV Pênfigo Vulgar

REDOME Registro Nacional de Doadores de Medula Óssea

RNA Ribonucleic acid (ácido ribonucleico)

RR Risco Relativo

SSO Sequence-specific Oligonucleotide (Oligonucleotídeo sequênciaespecífica)

USP Universidade de São Paulo

$\mu \mathrm{L} \quad$ microlitro 


\section{Lista de tabelas}

Tabela 1 - Genes do MHC associados ao pênfigo vulgar em diferentes populações

Tabela 2 - Alelos do locus HLA-DRB1 associados ao pênfigo vulgar em diferentes populações em todo o mundo

Tabela 3 - Distribuição de acordo com sexo e cor da pele dos indivíduos incluídos no estudo

Tabela 4 - Distribuição de acordo com a faixa etária no momento do diagnóstico dos pacientes com pênfigo vulgar

Tabela 5 - Prevalência de sintomas otorrinolaringológicos nos 36 pacientes com pênfigo vulgar

Tabela 6 - Frequência de acometimento pelo pênfigo vulgar dos diferentes órgãos e regiões anatômicas nos 36 pacientes estudados

Tabela 7 - $\quad$ Prevalência fenotípica de cada alelo HLA locus A nos indivíduos estudados

Tabela 8 - Prevalência de cada alelo HLA locus B nos indivíduos estudados 46

Tabela 9 - Prevalência de cada alelo HLA locus DR nos indivíduos estudados

Tabela 10 - Alelos do locus DR dos 36 doentes com pênfigo vulgar de acordo com a nomenclatura NMDP

Tabela 11 - Prevalência dos alelos HLA-DRB1 associados ao pênfigo vulgar em casos e controles

Tabela 12 - Prevalência dos alelos HLA locus DR nos indivíduos estudados estratificados de acordo com a cor da pele

Tabela 13 - Frequências do alelo DRB1*08:04 em amostras de diferentes populações do mundo 


\section{Lista de figuras}

Figura 1 - O desmossomo ........................................... 7

Figura 2 - Possíveis autoantígenos presentes nos desmossomos ......... 8

Figura 3 - Manifestações clínicas no pênfigo vulgar: cavidade oral ..... 10

Figura 4 - Manifestações clínicas no pênfigo vulgar: cavidade oral ..... 11

Figura 5 - Manifestações clínicas no pênfigo vulgar: pele .............. 12

Figura 6 - Diagnóstico imuno-histológico no pênfigo vulgar ........... 13

Figura 7 - Estrutura das moléculas de HLA Classes I e II ................ 19

Figura 8 - Prevalência fenotípica de cada alelo HLA locus A nos indivíduos estudados de acordo com o grupo .............. 45

Figura 9 - Prevalência de cada alelo HLA locus B nos indivíduos estudados de acordo com o grupo ....................... 48

Figura 10 - Prevalência de cada alelo HLA locus DR nos indivíduos estudados de acordo com o grupo $\ldots \ldots \ldots \ldots \ldots \ldots \ldots \ldots \ldots \ldots . . \ldots$

Figura 11 - Princípio de Hardy-Weinberg para dois alelos .............. 77 


\section{Resumo}

Weber R. Estudo da associação entre antígenos de histocompatibilidade leucocitária (HLA) e pênfigo vulgar em pacientes brasileiros [tese]. São Paulo: Faculdade de Medicina, Universidade de São Paulo; 2010.

INTRODUÇÃO: O Pênfigo Vulgar é uma doença bolhosa crônica que acomente pele e mucosas. A perda de adesão epitelial ocorre por agressão autoimune às desmogleínas presentes nos desmossomos, mediada por anticorpos IgG. Estudos sobre a gênese da autoimunidade no pênfigo indicam associação entre alelos do sistema HLA, especialmente dos loci DR e DQ. A população brasileira apresenta características favoráveis a estudos exploratórios em genética decorrente de sua origem mista e intensa miscigenação. PACIENTES E MÉTODO: O grupo em estudo incluiu trinta e seis pacientes não consanguíneos com diagnóstico de Pênfigo Vulgar comprovado por imunopatologia provenientes do estado de São Paulo, Brasil. Foram tipados para os loci HLA-A, HLA-B e HLA-DR utilizando-se oligonucleotídeos sequência-específica (PCR-SSO). As frequências alélicas e fenotípicas encontradas foram comparadas com as de um grupo controle composto de dados de 712 indivíduos doadores voluntários cadastrados no Registro Nacional de Doadores de Medula Óssea (REDOME) provenientes de São Paulo e tipados pelo mesmo método. O valor de $\mathrm{P}$ crítico foi corrigido utilizando-se 
o método False Discovery Rate. RESULTADOS: Os alelos HLA-DRB1*04:02, DRB1*08:04 e DRB1*14 estiveram associados à doença com riscos relativos de 44,6, 18,6 e 4,8, respectivamente $(p<0,001)$. Não houve diferença estatisticamente significante entre as frequências de nenhum alelo dos loci HLA-A ou HLA-B entre os grupos. DISCUSSÃO: O alelo DRB1*04:02, diretamente, e o alelo DRB1*14, indiretamente por desequilíbrio de ligação com DQB1*05:03, estão associados com Pênfigo Vulgar em diversas populações ao redor do mundo, porém nenhum estudo semelhante observou associação com o alelo DRB1*08:04 em tamanha magnitude. Acreditamos que as associações encontradas em nosso estudo não sejam decorrentes de viés de estratificação populacional. É necessária, no entanto, a tipagem de loci adjascentes ao HLA-DR dos indivíduos do grupo em estudo para diferenciar se o risco à doença é inerente a estes alelos ou a algum outro nas proximidades, com o qual estariam em desequilíbrio de ligação. CONCLUSÕES: Os alelos HLA-DRB1*04:02, DRB1*08:04 e DRB1*14 estiveram associados ao Pênfigo Vulgar em pacientes brasileiros.

Descritores: Pênfigo Vulgar; Antígenos HLA; Antígenos HLA-A; Antígenos HLA-B; Antígenos HLA-DR; Genes Classe I do Complexo de Histocompatibilidade (MHC); Genes Classe II do Complexo de Histocompatibilidade (MHC) 


\section{Summary}

Weber R. Study of the association between HLA antigens and Pemphigus Vulgaris in brazilian patients [thesis]. São Paulo: Faculdade de Medicina, Universidade de São Paulo; 2010.

BACKGROUND: Pemphigus vulgaris is a chronic blistering disease affecting skin and mucous membranes. Autoimmune aggression to desmoglein in desmosomes, mediated by IgG antibodies, leads to loss of epithelial cell adhesion. Studies indicate association between some alleles of the HLA system and pemphigus vulgaris, mainly at the $D R$ and DQ loci. Brazilian population characteristics are conducive to genetic exploratory studies because of its various origins and intense ethnically admixture. PATIENTS AND METHODS: The study group consisted of thirty-six unrelated patients with clinical and immunopathological diagnosis of pemphigus vulgaris from a tertiary hospital in Sao Paulo - Brazil. HLA allele typing at the A, B and DR loci was performed after DNA extraction using polymerase chain reaction and sequence-specific oligonucleotide probes (PCR-SSO). Allele and phenotypic frequencies were compared to those from a control group composed by 712 individuals volunteer donors registered in a national registry of bone marrow donors (REDOME) from Sao Paulo, typed using the same method. False Discovery Rate method was used to adjust level of critical P values. RESULTS: The HLA$D R B 1^{*} 04: 02, D R B 1^{*} 08: 04$ and $D R B 1^{*} 14$ were associated with pemphigus 
vulgaris with relative risks of 44.6, 18.6 and 4.8 , respectively $(p<0.001)$. There was no significant difference between the frequencies of any allele of loci HLAA or HLA-B among the groups. DISCUSSION: The alleles DRB ${ }^{*} 04: 02$ and $D R B 1 * 14$ (indirectly through linkage disequilibrium with the $D Q B 1 * 05: 03$ ) are associated with pemphigus vulgaris in several populations worldwide, however, no similar study reported such magnitude of association between pemphigus vulgaris and DRB ${ }^{*} 08: 04$ allele. We consider that the association is not secondary to population stratification bias. HLA typing of nearby loci is required to differentiate if the association with pemphigus vulgaris is inherent to the HLA-DRB $1^{*} 08: 04$ allele or to another gene which is in linkage disequilibrium. CONCLUSIONS: The HLA-DRB1*04:02, DRB1*08:04 and DRB1*14 were associated with pemphigus vulgaris in Brazilian patients.

Descriptors: Pemphigus Vulgaris; HLA Antigens; HLA-A Antigens; HLA-B Antigens; HLA-DR Antigens; MHC Class I genes; MHC Class II Genes 


\section{INTRODUÇÃO}

Pênfigo é um termo derivado do Grego pemphix (bolha) para um grupo de doenças mucocutâneas autoimunes caracterizadas pela formação de bolhas epiteliais que afetam as superfícies cutâneas e/ou mucosas (1). Pênfigos acometem a pele e a mucosa oral podendo também envolver a mucosa do nariz, da conjuntiva, dos genitais, do esôfago, da faringe e da laringe ${ }^{(1)}$.

O Pênfigo Vulgar (PV) é a forma mais comum dos pênfigos, frequentemente acometendo a cavidade oral ${ }^{(2,3)}$. O paciente típico tem entre 30 e 60 anos de idade e apresenta vesículas, erosões e úlceras recidivantes, com curso crônico na mucosa oral e na pele, principalmente em regiões de maior atrito. Na história natural da doença, antes da introdução dos corticosteróides no seu tratamento, a morte decorrente da desidratação e das infecções sistêmicas secundárias no PV era relativamente comum ${ }^{(3-5)}$.

Pacientes com PV são diagnosticados em diversas populações ao redor do mundo ${ }^{(6)}$; sua incidência varia entre 0,1 a 1,6 casos a cada 100.000 habitantes/ano em diferentes grupos populacionais ${ }^{(7-10)}$. Não há, no entanto, estudos sobre a incidência do PV na população Brasileira.

A fisiopatologia do PV inclui a perda do contato célula-célula (acantólise) no epitélio, levando à formação de bolhas intra-epiteliais ${ }^{(1)}$. Isso é decorrente de dano aos desmossomos - estruturas responsáveis pela aderência das células às estruturas adjacentes e ao reconhecimento e sinalização célula- 
célula ${ }^{(11)}$ - provocado por autoanticorpos ${ }^{(12)}$. Há evidências diretas de que autoanticorpos contra Desmogleínas (Dsg) - moléculas de adesão das células epiteliais do grupo das caderinas, presentes nos desmossomos - são críticos na patogênese do PV ${ }^{(13-15)}$.

Diversos dados genéticos e epidemiológicos disponíveis sobre o PV indicam que a susceptibilidade da doença é herdada. Casos familiares de PV são relatados, porém são muito incomuns e esporádicos, e envolvem apenas parentes de primeiro grau ${ }^{(16-20)}$. Duas diferentes observações corroboram para o envolvimento de fatores genéticos na susceptibilidade ao PV ${ }^{(21)}$ : primeiro, um aumento significativo na prevalência de doenças autoimunes em familiares de primeiro grau de pacientes com PV comparados a familiares de controles saudáveis, levando à suspeita de que fatores genéticos que controlam a ocorrência geral de autoimunidade participam na susceptibilidade ao PV ${ }^{(22,23)}$; segundo, a presença de anticorpos anti-Dsg, um fenótipo parcial do processo autoimune do PV, são frequentemente detectados em parentes de primeiro grau assintomáticos de pacientes com PV, consistente com um padrão de herança dominante ${ }^{(24-26)}$. Diversas estratégias são disponíveis para a identificação de genes que participam da susceptibilidade de doenças autoimunes $^{(21)}$.

Uma vez que a raridade de casos familiares de PV inviabiliza a aplicação de Testes de Desequilíbrio de Transmissão com o intuito de identificar cossegregação de marcadores polimórficos e doença (ou fenótipo parcial), a estratégia mais indicada para identificar genes participantes da 
susceptibilidade ao pênfigo tem sido o uso de estudos tipo caso-controle com bases populacionais. Estes estudos permitem testar associações entre determinados fatores de risco e doença, baseando-se na comparação dos indivíduos afetados com os não afetados. Essa estratégia tem consistentemente demonstrado que o locus $^{+}$do Complexo Principal de Histocompatibilidade (MHC - da Língua Inglesa, Major Histocompatibility Complex) está associado ao $\mathrm{PV}{ }^{(21)}$.

O MHC representa o conjunto de genes responsável por codificar as moléculas de histocompatibilidade de cada espécie. Na espécie humana, é chamado de sistema Antígeno Leucocitário Humano (HLA - da Língua Inglesa, Human Leukocyte Antigen). O sistema HLA está envolvido na rejeição de transplantes, doenças autoimunes, susceptibilidade a infecções decorrentes de imunodeficiências além de outras situações clínicas ${ }^{(27)}$. Dentre as funções das moléculas HLA está a apresentação de pequenos peptídeos derivados de proteínas do próprio organismo (moléculas de classe I) ou de patógenos (moléculas de classe II) aos linfócitos $\mathrm{T}$, um processo que inicia a resposta imune adaptativa ${ }^{(27)}$. A associação de PV $\operatorname{com}$ alelos $^{\ddagger}$ do sistema HLA é relatada desde a década de 80 . Um resumo dos achados dos estudos realizados em diferentes populações é apresentado na tabela 1.

\footnotetext{
† Locus (plural = loci): "lugar" em latim, é o local fixo em um cromossomo onde está localizado determinado gene ou marcador genético.

₹ Cada alelo é uma de diversas formas alternativas de um mesmo gene, geralmente referindo-se a um lugar específico dentro do gene.
} 
Tabela 1 - Genes do Complexo Principal de Histocompatibilidade (MHC) associados ao Pênfigo Vulgar em diferentes populações

\begin{tabular}{|c|c|c|c|c|}
\hline \multirow[b]{2}{*}{ População } & \multicolumn{2}{|c|}{ Número de indivíduos } & \multirow[b]{2}{*}{ Alelos } & \multirow[b]{2}{*}{ Referências } \\
\hline & Pacientes & Controles & & \\
\hline Argentinos & 47 & 199 & $\begin{array}{l}\text { DRB1*04:02; DRB1*14:01; DR8; } \\
\text { DQB1*05:03; DQB1*03:02 }\end{array}$ & $(28)$ \\
\hline Espanhóis & 26 & 200 & $\begin{array}{l}\text { DRB1*04:02, DRB1*14:01; } \\
\text { DQB1*05:03, DQB1*03:02 }\end{array}$ & (29) \\
\hline Franceses & 37 & 106 & $\begin{array}{l}\text { DRB1*04:02, DRB1*14:01, DRB1*14:04; } \\
\text { DQB1*03:02; DQB1*05:03 }\end{array}$ & $(30)$ \\
\hline Indianos & 37 & 89 & $\begin{array}{l}\text { DRB1*14:04; } \\
\text { DQA1*01:01; DQB1*05:03 }\end{array}$ & (31) \\
\hline Iranianos & 38 & 57 & DRB $1 * 04: 02$ & $(32)$ \\
\hline Italianos & 61 & 128 & DRB1*04:02, DRB1*14:01; DQB1*05:03 & $(33,34)$ \\
\hline Japoneses & 86 & 642 & $\begin{array}{l}\text { A26; B15 } \\
\text { DRB1*04:03, DRB1*04:06; DRB1*14:01, } \\
\text { DRB1*14:05, DRB1*14:06; } \\
\text { DQB1*05:03; }\end{array}$ & (35-39) \\
\hline Judeus Ashkenazi & 26 & - & DR4, DQw8 & $(40)$ \\
\hline Mexicanos & 25 & 96 & DR14 (DR6) & $(41)$ \\
\hline Norte Americanos & 38 & 44 & DR4 Dw10 (DR6 like); & $(42-44)$ \\
\hline & 58 & 1899 & DRB1*04:02; DQB1*05:03 & $(45)$ \\
\hline Paquistaneses & 19 & - & DRB1*14:04; DQA1*01:01; DQB1*05:03 & (46) \\
\hline Sardenhos & 16 & - & DRB1*04:02; DQA1*03:01; DQB1*03:02 & $(47)$ \\
\hline Turcos & 33 & 100 & $\begin{array}{l}\text { B35; B44; Cw4; DR4; DR11; DR14; } \\
\text { DQ2; DQ4; DQ8; DQ7 }\end{array}$ & $(48)$ \\
\hline Venezuelanos & 49 & 101 & DRB1*04:02; DRB1*14:01 & (49) \\
\hline
\end{tabular}

Como apresentado, um grande número de diferentes alelos dos loci do sistema HLA são associados ao PV. Muitas vezes genes muito próximos são 
frequentemente herdados em conjunto - fenômeno denominado de desequilíbrio de ligação - e igualmente identificados como associados a doenças, quando na verdade apenas um realmente provoca suscetibilidade à doença ${ }^{(45)}$. Replicações destes estudos em diferentes populações são necessárias para identificar quais as variantes que realmente estão associadas à susceptibilidade à doença e quais as que na verdade são resultados falsopositivos ${ }^{(50)}$. A população brasileira é uma das mais heterogêneas do mundo, resultado de séculos de cruzamentos entre populações de diferentes origens ${ }^{(51)}$. A realização de estudos de associação em populações com esta característica é vantajosa, pois a intensa miscigenação aumenta as chances de quebra de ligação entre os genes. Não há estudos na população brasileira referentes a genes que conferem susceptibilidade ao Pênfigo Vulgar. 


\subsection{Objetivo}

O objetivo deste estudo foi tipificar alelos do sistema HLA dos loci A, B, DR de pacientes brasileiros portadores de PV, identificando aqueles associados à doença por meio da comparação da prevalência destes alelos com às de um grupo controle. 


\section{REVISÃO DA LITERATURA}

\subsection{A Biologia do Epitélio e os Desmossomos}

A integridade do tecido epitelial, formando uma barreira contínua contra o ambiente externo, depende de uma estrutura complexa e de um grupo de moléculas. A coesão entre os queratinócitos, células principais do epitélio, é extremamente importante para preservar a arquitetura do tecido e a função epitelial. Os queratinócitos mantém-se aderentes uns aos outros por meio dos desmossomos, e à membrana basal pelos hemidesmossomos ${ }^{(52)}$ (figura 1).
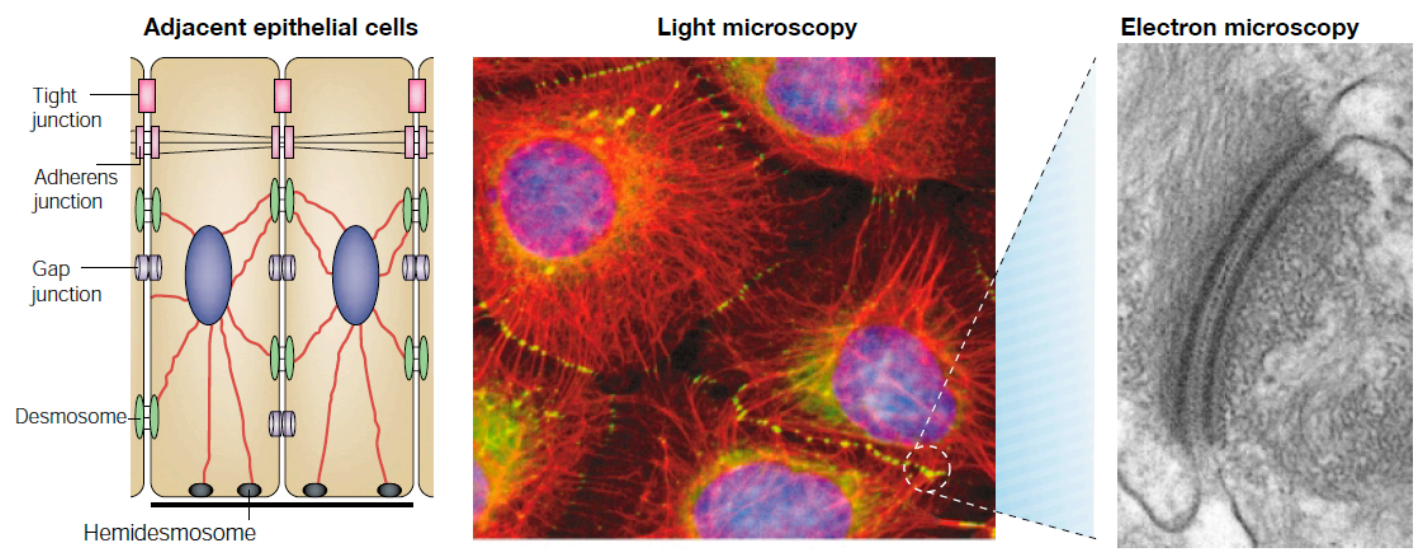

Figura 1: O desmossomo (desmosome), juntamente com as zonas de oclusão (tight junctions) e zonas de aderência (adherens junctions) formam o "complexo juncional" que promove união, comunicação e sinalização entre os queratinócitos do epitélio. Os hemidesmossomos (hemidesmosome) por sua vez conectam os queratinócitos à membrana basal. A imagem de microscopia (light microscopy) mostra que os tonofilamentos (em vermelho) conectam a camada de células pelos desmossomos, os quais estão evidentes em amarelo por coloração específica. A microscopia eletrônica (electron microscopy) ilustra a ultraestrutura altamente organizada de um desmossomo (Fonte: Green \& Gaudry, 2000 $0^{(53)}$ ). 
Cada componente consiste de diversas proteínas com importância não só de aderência, mas também de reconhecimento e sinalização célula a célula.

Os desmossomos são fundamentais para a adesão intercelular dos queratinócitos na mucosa oral e na pele. São proteínas de adesão com propriedade tanto de adesividade direta como de superfície para ancoragem dos filamentos intermediários de queratina do citoesqueleto, formando um emaranhado tridimensional que confere resistência mecânica ao tecido. Contém diversas proteínas, sendo as principais as demogleínas (Dsg) e as desmocolinas ${ }^{\left(52,{ }^{53)}\right.}$ (figura 2). As Dsg são glicoproteínas transmembrana de 130kD, da família das caderinas, que terão participação importante na fisiopatogenia do PV.

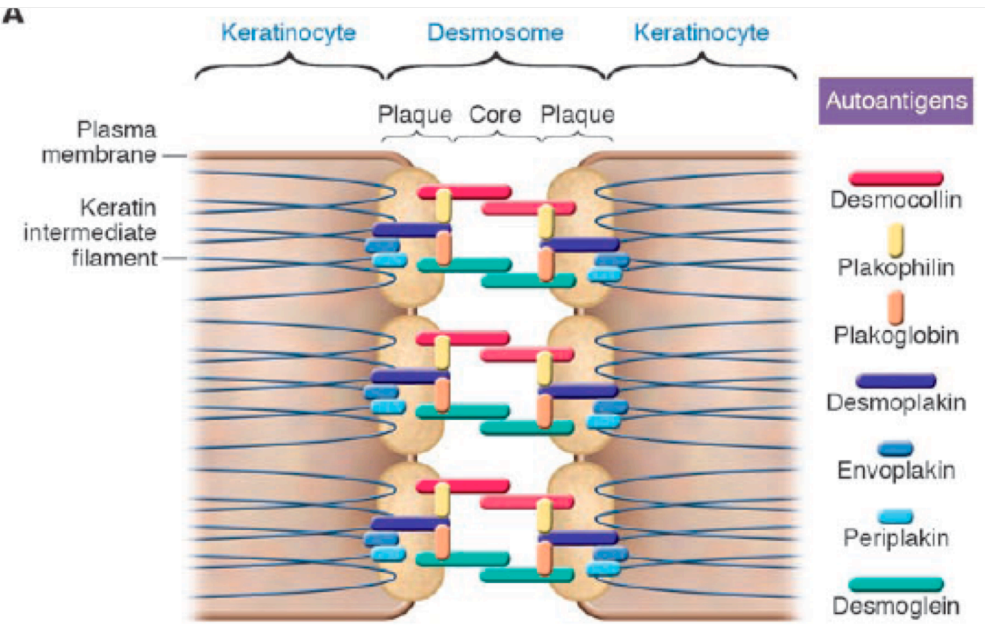

Figura 2: Possíveis autoantígenos presentes nos desmossomos. A Desmogleína é o alvo no Pênfigo Vulgar, enquanto os outros componentes estão envolvidos em outras variantes do Pênfigo (Fonte: Hertl, Eming \& Veldman, $2006^{(54)}$ ). 


\subsection{Pênfigo Vulgar}

\subsubsection{Epidemiologia}

Diversos estudos pesquisaram a incidência do PV em populações distintas. São relatadas incidências anuais de PV a cada 100.000 habitantes de 0,08 na Finlândia ${ }^{(55)}$, 0,2 na Arábia Saudita ${ }^{(8)}, 0,25$ na Sicília ${ }^{(56)}$ e região mediterrânea da Turquia ${ }^{(57)}$, 0,44 na Macedônia ${ }^{(58)}$, 0,47 na Bulgária ${ }^{(7)}$, 0,68 no Reino Unido ${ }^{(59)}$, 0,8 na Grécia ${ }^{(60)}$ e até 1,6 casos novos cada 100.000 habitantes acima de 20 anos de idade por ano em Israel ${ }^{(10)}$. Não foram localizados na literatura pesquisada estudos sobre a incidência do PV na população brasileira.

O início da doença ocorre mais frequentemente entre a quarta e sexta década de vida, porém podem ser afetados indivíduos de qualquer idade, sendo mais raro em crianças ${ }^{(61,62)}$. Embora de maneira geral não existam diferenças significativas entre os gêneros, vários estudos vêm demonstrando maiores prevalência e incidência no sexo feminino entre pacientes adultos ${ }^{(3,7}$, 57-59, 63) 


\subsubsection{Aspectos Clínicos}

O PV acomete principalmente a pele e a mucosa oral e pode também afetar as mucosas do nariz, conjuntiva, genitais, esôfago, faringe e laringe ${ }^{(1,64)}$. Tipicamente tem curso crônico, quase invariavelmente causando vesículas, erosões e úlceras na mucosa oral e na pele ${ }^{(3)}($ figura 3).

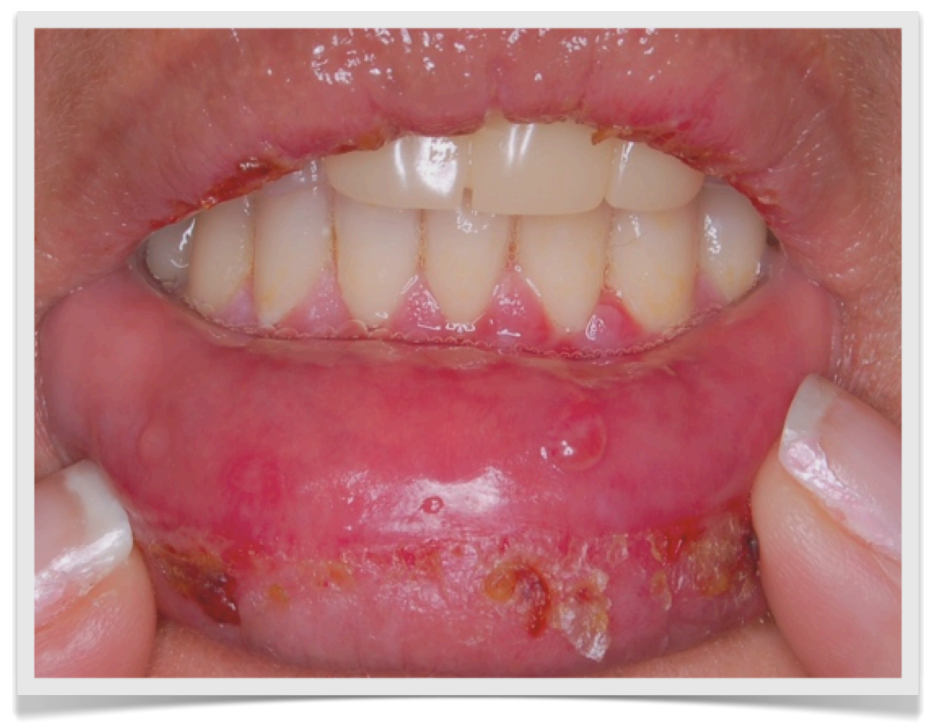

Figura 3: Manifestações clínicas do Pênfigo Vulgar: cavidade oral. Lesão bolhosa em mucosa de lábio inferior. Observam-se também descamação do vermelhão do lábio e gengivite descamativa leve junto aos incisivos inferiores.

O envolvimento oral no PV é muito frequente, havendo relatos de sua presença entre 66 a $92 \%$ dos pacientes ${ }^{(1)}$. O surgimento das lesões orais 
precede o das lesões cutâneas entre 50 a $72 \%$ dos pacientes $\left.{ }^{(61,} 65\right)$. Inicialmente vésico-bolhosas, as lesões orais rapidamente se rompem em função do trauma da movimentação constante promovida pela fala e pela deglutição. Assim, úlceras e erosões são as lesões mais frequentemente observadas ao exame clínico, principalmente em mucosa de bochechas, palato e lábios ${ }^{(1,3,10,66)}$ (figura 4).

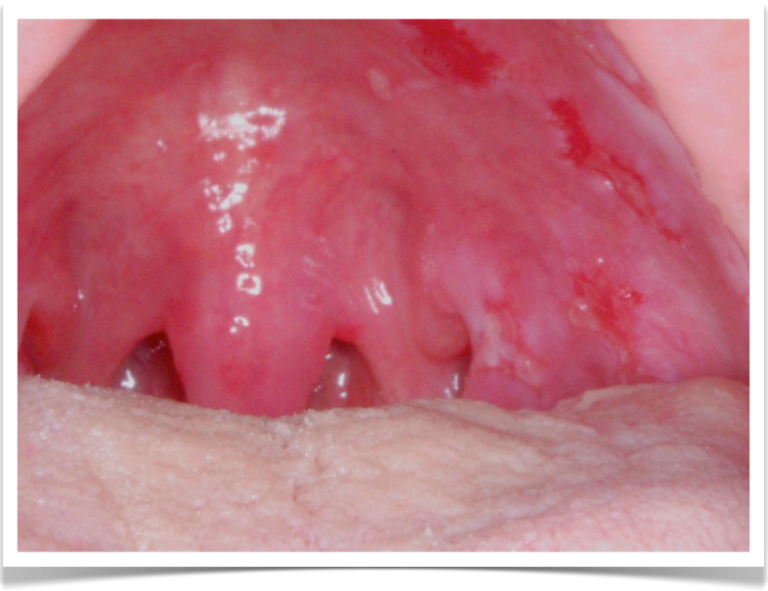

Figura 4: Manifestações clínicas do Pênfigo Vulgar: cavidade oral. Lesões ulceradas em mucosa de palato, observadas após o rompimento das bolhas.

As lesões gengivais são menos comuns e inicialmente aparecem como bolhas e/ou erosões de pequena extensão. Seu avanço, porém, geralmente resulta em severa gengivite descamativa ou erosiva, na qual as bolhas se rompem e deixam fragmentos de epitélio esfoliados ou úlceras profundas, principalmente na gengiva fixa ${ }^{(3,67)}$ (figura 3 ). Lesões orais avançadas, assim como lesões faríngeas e laríngeas são dolorosas e dificultam a alimentação, podendo haver comprometimento do estado nutricional ${ }^{(64)}$. 
Na pele, as lesões primárias são bolhas flácidas que surgem no tecido normal ou eritematoso. As bolhas são frágeis e rompem-se rapidamente, formando erosões dolorosas, facilmente sangrantes e recobertas por crostas hemáticas ${ }^{(61)}$. A realização de pressão na pele aparentemente normal próxima à lesão pode induzir ao descolamento epidérmico, o que é conhecido como sinal de Nikolsky, indicando doença em atividade. As bolhas podem ser localizadas ou generalizadas, e qualquer área da pele pode ser envolvida (figura 5).

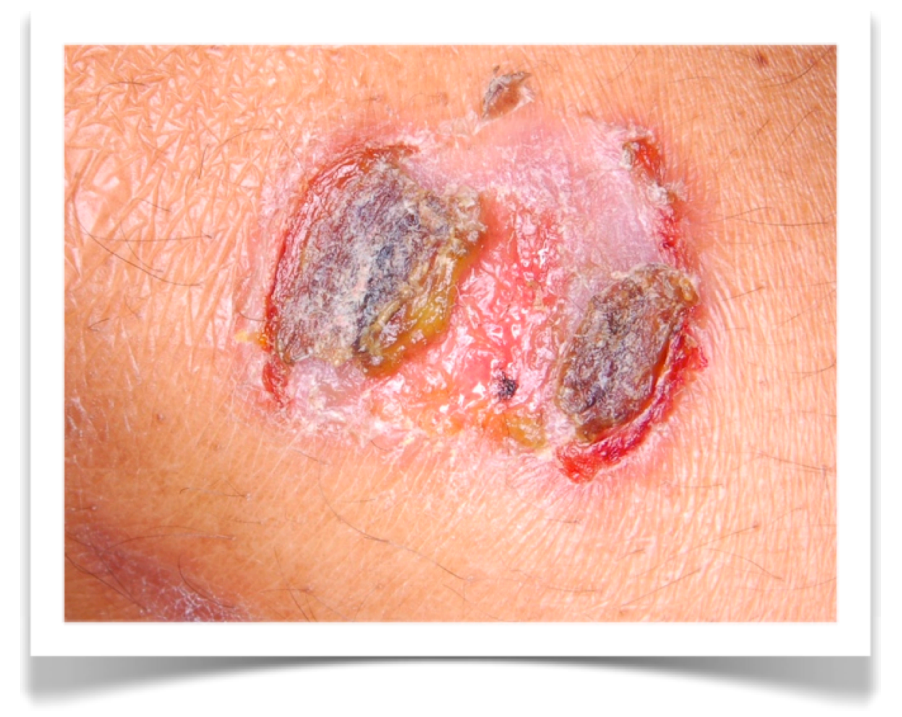

Figura 5: Manifestações clínicas do Pênfigo Vulgar: pele. Lesão ulcerada na pele do antebraço recoberta por crostas hemáticas. 


\subsubsection{Diagnóstico}

Os sinais clínicos do PV - lesões vesicobolhosas, erosivas ou ulceradas afetando mucosas e pele ou mesmo o sinal de Nikolsky - não são específicos do PV, e estão presentes em outras dermatoses autoimunes. Portanto, para o correto diagnóstico, são necessários exames complementares. É fundamental estabelecer o diagnóstico de PV o mais precocemente possível para que o tratamento adequado possa ser iniciado. Assim, além de anamnese e exame físico minuciosos, estão indicados exames histopatológicos e imunológicos de biópsia perilesional ${ }^{(1)}$. A histopatologia no PV é caracterizada pela formação de bolha intraepidérmica logo acima da camada basal (figura 6A). A imunofluorescência direta (IFD) mostra depósitos de IgG e complemento na superfície dos queratinócitos em toda epiderme (figura 6B), em todos os casos com doença em atividade.
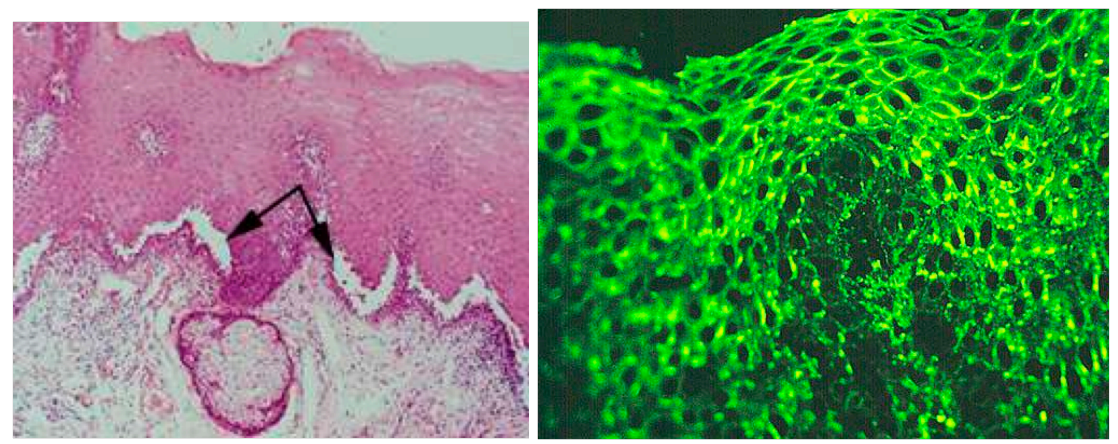

Figura 6: Diagnóstico imuno-histológico no Pênfigo Vulgar. (A) Exame anátomopatológico (hematoxilina-eosina, 40x) evidenciando bolha intraepidérmica com nível de clivagem suprabasal (setas). (B) imunofluorescência direta evidenciando depósitos de IgG e C3 na superfície dos queratinócitos da epiderme. 
O diagnóstico de PV também pode ser confirmado utilizando-se sangue periférico do paciente por meio de testes de imunofluorescência indireta (IFI) ou da pesquisa de anticorpos circulantes $\lg G$ anti-desmogleínas 1 e 3 recombinantes utilizando métodos ELISA ou immunoblot. $\mathrm{Na}$ IFI, os autoanticorpos IgG circulantes são detectados usando pele de prepúcio humano, esôfago de macacos ou bexiga de macaco ou roedores como substrato $^{(68)}$. Amagai e colaboladores ${ }^{(69)}$ relatam respectivamente sensibilidade e especificidade no diagnóstico de PV de 97,9\% e 98,9\% utilizando o método ELISA para detecção de autoanticorpos contra Dsg1 e 97,5\% e 97,8\% para Dsg3.

\subsubsection{Fisiopatologia}

\subsubsection{Autoanticorpos Antidesmossomos}

O mecanismo fisiopatológico que leva às manifestações clínicas do PV é provocado por dano aos desmossomos do epitélio por autoanticorpos (subclasse IgG) direcionados contra os domínios extracelulares das Dsg. Tal relação causa-efeito é comprovada por modelos experimentais: Pulkkinen e colaboradores ${ }^{(70)}$ demonstram que a deleção do gene da Dsg3 em ratos pode determinar a perda da adesão celular epitelial, ocorrendo perda do contato 
entre as células (acantólise) e consequente vesiculação intraepitelial ${ }^{(12)}$ - figura 6A. Amagai e colaboradores (71) confirmam a participação direta de autoanticorpos contra Dsg por meio da indução de doença bolhosa cutânea (semelhante ao PV) após a inoculação em ratos recém-nascidos de anticorpos IgG contra Dsg obtidos a partir do soro de pacientes com PV.

\subsubsection{Imunidade Celular}

A presença de linfócitos $\mathrm{T}$ autorreativos que reconhecem o domínio extracelular das Dsg deve ser crítico na patogênese do PV, uma vez que a ativação de linfócitos B para produção de autoanticorpos requer a participação de linfócitos $\mathrm{T}(\mathrm{LT})$ auxiliares $\left(\mathrm{CD} 4^{+}\right)$. No entanto, o fator inicial para deflagração do processo autoimune permanece obscuro ${ }^{(1)}$. A forte associação entre PV e diferentes alelos do sistema HLA - que serão pormenorizados posteriormente - sugere o envolvimento de LT auxiliares na gênese do PV. O reconhecimento de epítopos ${ }^{\dagger}$ das Dsg deve ser crucial para a iniciação e perpetuação da produção de autoanticorpos específicos pelos linfócitos B ${ }^{(72)}$. Linfócitos B secretores de $\lg$ específica para Dsg3 são detectados em estimulação in vitro de linfócitos periféricos de pacientes com PV ${ }^{(73)}$. A depleção de LT auxiliares leva à inativação das células B autorreativas, e a produção de IgG por estas células também é abolida quando anticorpos monoclonais anti-HLA-DR ou -DQ são adicionados às culturas ${ }^{(73)}$.

\footnotetext{
† Epítopo: menor parte de um antígeno capaz de estimular resposta imunológica.
} 
Tais achados sugerem fortemente que as células B circulantes específicas para Dsg3 são reguladas por LT auxiliares controlados por HLA classe II ${ }^{(54)}$. Veldman e colaboradores ${ }^{(74)}$ observam respostas de LT auxiliares contra epítopos de Dsg3 não apenas em doentes com pênfigo vulgar, mas também em controles saudáveis familiares portadores de determinados HLA-DR e HLADQ.

\subsubsection{Evidências de Participação Genética na Susceptibilidade ao}

\section{Pênfigo Vulgar}

Diversos dados genéticos e epidemiológicos sobre o Pênfigo indicam que a susceptibilidade da doença é herdada. Diferente de outras doenças, como a Anemia Falciforme, na qual todos os indivíduos geneticamente suscetíveis têm a doença e os portadores são facilmente detectados, a genética de doenças autoimunes é muito menos clara. Apesar de muitas doenças autoimunes, como a Espondilite Anquilosante, a Artrite Reumatóide, a Glomerulonefrite Membranosa Idiopática e a Psoríase Vulgar demonstrarem associação com genes do $\mathrm{MHC}{ }^{(75,76)}$, indivíduos geneticamente suscetíveis podem não desenvolver a doença e portadores geralmente não são detectáveis. Este fenômeno é chamado de penetrância incompleta ${ }^{(24)}$. 
Outro fato que sugere envolvimento genético no PV é a presença de baixos níveis de autoanticorpos (anti-caderinas) detectados utilizando técnicas de Western-Blot e IFD e IFI entre 34 a $71 \%$ de familiares de primeiro grau (pais, filhos e irmãos) assintomáticos de pacientes portadores da doença ${ }^{(24-26)}$. O padrão de herança encontrado nas famílias estudadas é compatível com o padrão genético Mendeliano dominante. Tais achados sugerem que a doença ocorre em razão de uma susceptibilidade individual genética, porém outros fatores ainda desconhecidos, ambientais ou genéticos, são necessários para induzir altos níveis de anticorpos suficientes para o desenvolvimento de bolhas.

Estudos do tipo caso-controle com bases populacionais buscam associação entre um determinado fator de risco e uma doença e baseiam-se na comparação de indivíduos afetados com não afetados. Essa estratégia tem consistentemente demonstrado que o MHC está associado ao $\mathrm{PV}^{(21)}$. 


\subsection{O Complexo Principal de Histocompatibilidade e o Sistema de Antígeno Leucocitário Humano}

\subsubsection{Genes do Sistema HLA Classes I e II e Nomenclatura}

Os genes de histocompatibilidade são assim chamados porque, quando descobertos, foram relacionados com a rápida rejeição de tecidos transplantados entre animais de experimentação, sendo em conjunto denominados Complexo Principal de Histocompatibilidade (MHC - da Língua Inglesa, Major Histocompatibility Complex). Assim, o MHC representa o conjunto de genes responsável por codificar as moléculas de histocompatibilidade em uma determinada espécie, sendo na espécie humana denominado de sistema HLA (da língua Inglesa, Human Leukocyte Antigen) ${ }^{(77)}$. O complexo HLA está situado no cromossomo 6 e contém cerca de 200 genes; mais de 40 deles codificam antígenos leucocitários ${ }^{(27)}$. Muitos genes desse complexo não estão relacionados com imunidade. Os genes HLA que estão envolvidos com a resposta imune pertencem a duas classes, I e II, os quais são estruturalmente e funcionalmente diferentes (figura 7). 


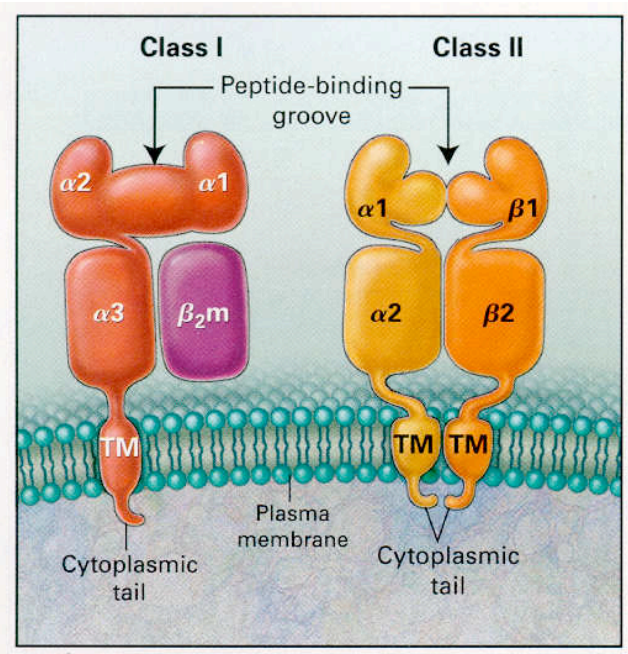

Figura 7: Estrutura das moléculas de HLA Classe I e Classe II. $\beta$-2microglobulina ( $\beta 2 \mathrm{~m}$ ) é a cadeia leve da molécula de Classe I. A cadeia $\alpha$ da molécula de classe I tem dois domínios de ligação a peptídeos: $\alpha 1$ e $\alpha 2$, um domínio semelhante à imunoglobulina $\alpha 3$, a região transmembrana (TM), e a cauda citoplasmática (citoplasmic tail). Cada uma das cadeias $\alpha$ e $\beta$ de classe II tem quatro domínios: o sítio de ligação a peptídeos (peptide-binding domain) ( $\alpha 1$ ou $\beta 1$ ), o domínio semelhante à imunoglobulina ( $\alpha 2$ ou $\beta 2)$ a região transmembrana (TM), e a cauda citoplasmática (citoplasmic tail). Plasma membrane = membrana citoplasmática. (Fonte: Klein e Sato, $2000^{(27)}$ )

Os genes de classe I codificam polipeptídeos para a cadeia $\alpha$ das moléculas de classe I. Existem cerca de 20 genes classe I na região HLA; três destes, HLA-A, B, e C, chamados clássicos, são os principais envolvidos no cenário imunológico ${ }^{(27)}$.

Os genes de classe II codificam polipeptídeos para as cadeias $\alpha$ e $\beta$ das moléculas de classe II. A designação dos seus loci no cromossomo 6 consistem de três letras: a primeira (D), indica a classe, a segunda $(M, O, P, Q$, ou R) a família, e a terceira, (A ou B) a cadeia ( $\alpha$ ou $\beta$, respectivamente). HLA-DRB, por exemplo, se refere a genes classe II da família $\mathrm{R}$ codificando cadeias $\beta$. Os 
genes individuais são diferenciados por algarismos arábicos, e a notação das numerosas variantes alélicas desses genes é um número precedido por um asterisco. Por exemplo, HLA-DRB1*04:01 se refere à variante alélica 04:01 do gene 1 , o qual codifica a cadeia $\beta$ de uma molécula classe II pertencente à família R.

Os genes HLA são codominantes; isto significa que há expressão tanto dos genes de origem materna quanto paterna.

Os genes de classe I são expressos pela maioria das células somáticas ${ }^{\dagger}$, embora a expressão varie de acordo com o tecido. Em contraste, os genes de classe II são expressos apenas por um subgrupo de células do sistema imune, incluindo linfócitos B, linfócitos T ativados, macrófagos, células dendríticas ${ }^{\ddagger}$ e células epiteliais do timo. A função de ambas moléculas classes I e II é a apresentação de pequenos peptídeos derivados de patógenos para os linfócitos T, um processo que inicia a resposta imune adaptativa ${ }^{(27)}$.

† Células somáticas: quaisquer células dos organismos multicelulares que não estejam diretamente envolvidas na reprodução

* Células dendríticas: células apresentadoras de antígenos presentes na pele (onde são denominadas de células de Langerhans), e nas mucosas dos aparelhos digestório e respiratório. 


\subsubsection{Mecanismo de Apresentação de Antígenos}

Todas as células são equipadas com um sistema de eliminação e reciclagem de resíduos. Os organismos menos complexos não fazem distinção entre peptídeos próprios e aqueles derivados de proteínas estranhas. Na escala de evolução, a partir dos vertebrados dotados de mandíbula, esse sistema passou a ser adaptado para a defesa do organismo contra patógenos. Assim, estes vertebrados utilizam peptídeos derivados do organismo estranho (geralmente vírus, bactérias, fungos ou protozoários) para marcar as células infectadas que devem ser destruídas. Enquanto as moléculas HLA de classe I na superfície das células apresentam amostras dos peptídeos produzidos continuamente no interior da célula, as moléculas de classe II, em linfócitos B, macrófagos e células dendríticas - células especializadas em endocitose e fagocitose - apresentam peptídeos das proteínas estranhas ao organismo que foram internalizadas via endocitose. Linfócitos $T$ altamente específicos ao se ligarem aos complexos molécula HLA associada a peptídeos estranhos, dão início à resposta imune, levando a sua proliferação celular ${ }^{(27)}$. 


\subsection{Importância da identificação dos alelos do sistema HLA associados ao PV para elucidação de sua fisiopatologia}

A possibilidade de alelos do sistema HLA conferirem risco ou proteção para determinadas doenças, associado à presença de inconsistências sobre quais alelos estão realmente associados ao PV, revela a importância da genotipagem constante de pacientes com PV ${ }^{(45)}$. A informação genética pode elucidar as vias envolvidas na doença e identificar novos alvos para intervenções terapêuticas, avanços que são de interesse na pesquisa básica e aplicada. O esclarecimento genético pode levar a avanços no diagnóstico ou à capacidade de uso de agentes terapêuticos mais eficientes e com menores riscos de efeitos adversos ${ }^{(78)}$.

A primeira tarefa na definição dos requisitos necessários para o complexo molécula HLA-autoantígeno-receptor de linfócitos T que levam a uma reação autoimune viável é esclarecer quais moléculas realmente conferem risco ao PV. Certos alelos que foram associados à doença baseandose apenas na análise de frequência podem não ser realmente relevantes (ou seja, não desempenham papel na patogênese da doença), e sim serem mais prevalentes na doença por existir desequilíbrio de ligação (linkage disequilibrium) com genes realmente promotores de susceptibilidade ${ }^{(45)}$. Maiores informações sobre o equilíbrio de Hardy-Weinberg e sobre o desequilíbrio de ligação estão detalhadas no anexo A. 


\subsection{Base estrutural para susceptibilidade ao Pênfigo Vulgar de portadores do alelo HLA DRB1*04:02}

O fato de peptídeos do próprio organismo serem apresentados como estranhos por algumas moléculas HLA e não por outras fornece presumivelmente a base da associação de cada doença com um alelo específico ${ }^{(79)}$. Suporte contundente a esta interpretação é dada pelos achados em pacientes com PV. O alelo HLA DRB1*04:02 está fortemente associado ao PV em judeus Ashkenazi (40), franceses (30), italianos (33, 34), sardenhos (47), espanhóis ${ }^{(29)}$, norteamericanos ${ }^{(42-44)}, \operatorname{turcos}^{(48)}$, argentinos ${ }^{(28)}$ e venezuelanos ${ }^{(49)}$. Wucherpfennig e colaboladores ${ }^{(80)}$, analisando a estrutura do envelope do sítio de ligação aos peptídeos da molécula de HLA DRB1*04:02, demonstram que a presença de um bolsão negativo (provocado pela carga negativa de aminoácidos nas posições 71 - aspartato - e 74 - glutamato), aumenta sua afinidade seletiva para a apresentação de um peptídeo da Dsg. Esta interação fornece uma base estrutural para justificar a associação entre DRB1*04:02 e a autoimunidade no PV, uma vez que a apresentação de um autoantígeno (a Dsg) levaria ao estímulo de linfócitos $\mathrm{T}$ específicos, que por sua vez estimulariam linfócitos B para a produção de anticorpos anti-desmogleínas. Outros estudos ${ }^{(74,81)}$ confirmam a idéia de que os portadores de alelos HLA classe II específicos estão geneticamente em risco de desenvolver respostas de LT auxiliares Dsg3-específica independente do desenvolvimento de PV, e que 
os LT auxiliares autoagressivos realmente reconhecem um conjunto limitado de peptídeos da Dsg3.

\subsection{Associação entre outros Alelos do Sistema HLA e Pênfigo Vulgar}

Estudos populacionais de pacientes com PV demonstram que existem diferenças entre os alelos mais prevalentes entre as diferentes etnias e populações. Os nove alelos DRB1 associados ao PV (DRB1*04:02, *04:03, *04:06, *08:02, *08:04, *14:01, *14:04, *14:05, *14:08) em 13 diferentes populações estão sumarizados na tabela 2. 
Tabela 2 - Alelos do locus HLA-DRB1 associados ao PV relatados em diferentes populações em todo o mundo

\begin{tabular}{|c|c|c|c|}
\hline Alelo & Populações & RR (IC 95\%) & Referências \\
\hline \multicolumn{4}{|l|}{ DRB1 } \\
\hline \multirow[t]{2}{*}{ 04:02 } & Argentinos & $18,2(20,8-155,7)$ & $(28)$ \\
\hline & Espanhóis & $100,8(30,3-337,1)$ & (29) \\
\hline \multirow[t]{2}{*}{ (DR4) } & Europeus não-judeus & - & (44) \\
\hline & Franceses & $91,6(5,5-1452,0)$ & (30) \\
\hline \multirow[t]{7}{*}{ (DR4) } & Judeus Ashkenazi & - & $(40)$ \\
\hline & & $5,0(2,2-11,4)$ & (45) \\
\hline & Iranianos & & $(32)$ \\
\hline & Italianos & $26,9(4,2-92,4)$ & $(47)$ \\
\hline & & $15,2(4,9-47,2)$ & (34) \\
\hline & Norte Americanos & $34,0(12,2-89,4)$ & $(45)$ \\
\hline & Sardenhos & $127,1(6,2-286,2)$ & $(47)$ \\
\hline 04:02 & Venezuelanos & $22,3(4,7-100,8)$ & (49) \\
\hline 04:03 & Japoneses & - & (35) \\
\hline \multirow[t]{2}{*}{ 04:06 } & Japoneses & $9,8(3,5-27,2)$ & (38) \\
\hline & & $17,5(4,5-68,1)$ & (35) \\
\hline 08:02 & Japoneses & $21,5(4,4-104,2)$ & (39) \\
\hline 08:04 & Italianos & $32,5(3,3-378,4)$ & $(47)$ \\
\hline \multirow[t]{8}{*}{$14: 01$} & Argentinos & $12,9(4,9-34,1)$ & (28) \\
\hline & Espanhóis & $8,8(3,1-28,3)$ & (29) \\
\hline & Europeus não-judeus & $13,2(6,0-29,1)$ & (46) \\
\hline & Franceses & $3,1(0,8-10,2)$ & (30) \\
\hline & Italianos & $23,3(3,3-31,4)$ & $(47)$ \\
\hline & & $6,0(2,9-12,5)$ & (34) \\
\hline & Japoneses & $11,2(3,6-34,9)$ & (38) \\
\hline & Judeus & - & (43) \\
\hline
\end{tabular}


Tabela 2 (conclusão) - Alelos do locus HLA-DRB1 associados ao PV relatados em diferentes populações em todo o mundo

\begin{tabular}{|c|c|c|c|}
\hline Alelo & Populações & RR (IC 95\%) & Referências \\
\hline \multicolumn{4}{|l|}{ DRB1 } \\
\hline \multirow[t]{3}{*}{ (DR14) } & Mexicanos & - & $(41)$ \\
\hline & Sardenhos & $9,9(1,2-57,6)$ & $(47)$ \\
\hline & Venezuelanos & 47,6 & (49) \\
\hline \multirow[t]{4}{*}{$14: 04$} & Franceses & $17,2(1,1-381,3)$ & (30) \\
\hline & Indianos & $5,5(2,5-11,7)$ & (31) \\
\hline & Italianos & $24,2(3,1-190,7)$ & (34) \\
\hline & Paquistaneses & $12,1(1,4-12,5)$ & $(46)$ \\
\hline 14:05 & Japoneses & $9,3(2,7-31,6)$ & $(38,39)$ \\
\hline $14: 08$ & Japoneses & $9(4,8-2.022,9)$ & (39) \\
\hline
\end{tabular}




\subsection{Particularidades da Formação da População Brasileira}

A população Brasileira é a mais heterogênea do mundo, resultado principalmente de cinco séculos de cruzamentos interétnicos entre populações de três continentes: européias, africanas e ameríndias. Quando os portugueses chegaram no ano 1500, existiam aproximadamente 2,5 milhões de índios vivendo na área que corresponde hoje ao Brasil ${ }^{(82)}$. A mistura PortuguêsAmeríndio iniciou logo após a chegada dos primeiros colonizadores. Tornouse comum e passou a ser encorajada após o ano 1755, como estratégia para o crescimento populacional e ocupação colonial do território ${ }^{(83)}$. A partir da metade do século XVI, africanos foram trazidos ao Brasil como escravos para trabalho em fazendas de cana-de-açúcar e, posteriormente, em minas de ouro e diamante e em plantações de café. Registros históricos sugerem que entre 1551 e 1850 (período em que o comércio de escravos era permitido) cerca de 3,5 milhões de africanos foram trazidos ao Brasil ${ }^{(84)}$. Em relação à imigração européia, estima-se que cerca de 500.000 portugueses desembarcaram no Brasil entre 1500 e 1808. A partir de então, os portos Brasileiros foram legalmente abertos para nações amigas, e o Brasil recebeu cerca de 4 milhões de imigrantes de diversas partes do mundo. Portugal permaneceu como a origem mais frequente, seguida por Itália, Espanha e Alemanha ${ }^{(82)}$.

Durante os censos periódicos realizados pelo Instituto Brasileiro de Geografia e Estatística (IBGE) ${ }^{(85)}$, cada indivíduo é classificado dentro de uma 
de cinco raças: branca, preta, amarela (oriental), parda (mulata, cabocla, cafuza, mameluca ou mestiça de preto com outra cor ou raça) ou indígena. Contudo, Pimenta e colaboradores ${ }^{(51)}$ demonstram (utilizando microsatélites forenses e marcadores-indicadores específicos de ascendência européia ou africana) que na população brasileira, em nível individual, não há correlação entre a cor da pele (ou raça) e a ancestralidade. 


\section{CASUÍSTICA E MÉTODO}

O presente estudo foi aprovado pelo comitê de ética em pesquisa do Hospital das Clínicas da Faculdade de Medicina da USP (CAPPesq), conforme resolução número 1045/06 (anexo B).

O desenho do estudo foi observacional caso-controle.

\section{1 - CASUÍSTICA}

\subsubsection{GRUPO DE PACIENTES COM PÊNFIGO VULGAR}

Os indivíduos elegíveis para o estudo foram provenientes dos ambulatórios de Estomatologia da Divisão de Clínica Otorrinolaringológica e de Doenças Bolhosas da Divisão de Clínica Dermatológica do Hospital das Clínicas da Faculdade de Medicina da Universidade de São Paulo.

Todos foram convidados a participar do estudo, e somente o fizeram após o preenchimento e a assinatura do Termo de Consentimento Livre e 
Esclarecido (anexo C). No caso de pacientes com idade inferior a 18 anos, a participação foi condicionada à aprovação dos pais ou responsáveis legais.

Foram utilizados como critérios de inclusão para que o paciente pudesse participar do estudo:

1) Diagnóstico prévio de Pênfigo Vulgar pelo cumprimento de todos os seguintes critérios:

a.) clínico: história e exame físico de doença bolhosa envolvendo mucosas e/ou pele;

b.) histopatológico: disponibilidade de biópsia de pele ou mucosa evidenciando acantólise e clivagem suprabasal (figura 6A);

c.) imunopatológico: imunofluorescência direta ou indireta demonstrando anticorpos IgG ligando-se aos espaços intercelulares da epiderme (figura 6B).

Foram utilizados como critérios de exclusão para a participação no estudo:

1) Pacientes que apresentassem evidências de Pênfigo Paraneoplástico (secundário a neoplasias) ${ }^{(86)}$, de acordo com os critérios revisados por Camisa \& Helm ${ }^{(87)}$;

2) Pacientes que tivessem familiar consangüíneo já participando do estudo.

De um total de 37 indivíduos elegíveis para o grupo em estudo, os dados de uma paciente foram excluídos por apresentar parente consanguíneo 
(irmã), também com diagnóstico de PV, já participando do estudo. Assim, o grupo foi constituído de 36 pacientes, sendo 28 mulheres e oito homens.

\subsubsection{GRUPO CONTROLE}

Os dados do grupo controle foram obtidos a partir de um banco de dados de doadores voluntários de medula óssea. Este banco contém dados demográficos e referentes ao HLA de indivíduos cadastrados no programa Registro Nacional de Doadores de Medula Óssea (REDOME) ${ }^{(88)}$ os quais tiveram suas amostras de DNA tipadas no Laboratório de Imunologia de Transplantes do Instituto do Coração (INCOR) do Hospital das Clínicas da Faculdade de Medicina da Universidade de São Paulo. Foi composto por 712 indivíduos não relacionados cujas análises foram realizadas consecutivamente no referido laboratório entre janeiro de 2008 e abril de 2009. 


\subsection{MÉTODO}

\subsubsection{AVALIAÇÃO CLÍNICA E COLETA DE AMOSTRA DE SANGUE} PERIFÉRICO

Dados referentes ao gênero, idade e cor da pele foram coletados de cada paciente. A seguir, era realizada anamnese questionando-se a presença de sinais e sintomas de pênfigo vulgar, e revisado o prontuário à procura de registros da existência de lesões (ativas ou pregressas) nas mucosas oral, nasal, faríngea e laríngea ao exame de nasofibrolaringoscopia. Os dados foram coletados de maneira padronizada conforme protocolo criado previamente pelo autor (anexo D). A classificação da cor da pele (ou raça) foi a mesma utilizada pelo IBGE ${ }^{(85)}$, na qual a própria pessoa se classifica dentro de cinco categorias: branca, preta, amarela (oriental), parda (mulata, cabocla, cafuza, mameluca ou mestiça de preto com outra cor ou raça) ou indígena.

Após a anamnese, foi colhida uma amostra de $10 \mathrm{~mL}$ de sangue periférico de cada paciente em um tubo contendo $25 \mathrm{mM}$ de EDTA. As amostras foram conservadas em temperatura ambiente e levadas em até 12 horas para o laboratório onde foram realizadas as extrações do DNA. 


\subsubsection{EXTRAÇÃO E TIPIFICAÇÃO DO DNA}

A extração de DNA e a tipificação HLA de classes I e II foram realizadas no Laboratório de Imunologia de Transplantes do INCOR.

\subsubsection{EXTRAÇÃO DE DNA DE SANGUE TOTAL PELO} MÉTODO DTAB/CTAB

A extração de DNA da amostra de sangue periférico foi realizada pelo método DTAB/CTAB, conforme descrito por Olerup e Zetterquist ${ }^{(89)}$. Cada pellet de DNA ${ }^{\dagger}$ extraído foi diluído em tubos Eppendorf ${ }^{\circledR}$ de 1,5 mL contendo entre 50 a $200 \mu \mathrm{L}$ de água Milli-q (de acordo com a quantidade de DNA) e armazenados em geladeira com temperatura entre 1 e $4^{\circ} \mathrm{C}$. No dia seguinte à extração, a concentração de DNA foi medida em espectrofotômetro (comprimento de onda de 260 e 280 nm). O valor da razão entre as absorbâncias a 260 e 280 nm (A260/A280) deveria estar entre 1,8 e 2,0.

† Pellet de DNA: massa de DNA precipitado (quando diluído em etanol) condensada no fundo do tubo após centrifugação 
Valores inferiores indicam contaminação com proteínas e superiores, com RNA.

\subsubsection{TIPIFICAÇÃO HLA PELO MÉTODO PCR-SSO}

A tipificação do HLA nos loci A, B e DR foi realizada após a extração do DNA utilizando-se a Reação em Cadeia da Polimerase (PCR - da Língua Inglesa Polymerase Chain Reaction) e amplificação com oligonucleotídeos sequência-específica (SSO - da Língua Inglesa Sequence-Specific Oligonucleotide ${ }^{\left(90,{ }^{91)}\right.}$ por meio de kits LABType ${ }^{\circledR}$ (One Lambda, INC - Canoga Park, Califórnia, EUA). LABType ${ }^{\circledR}$ SSO utiliza sondas de oligonucleotídeos sequência específica ligados a microesferas codificadas fluorescentemente para identificar alelos correspondentes na amostra de DNA. LABType ${ }^{\circledR}$ aplica a tecnologia Luminex ${ }^{\circledR}$ para o método de tipificação de DNA SSO reverso. Inicialmente, o DNA alvo é amplificado via PCR utilizando um iniciador (primer) grupo específico. O produto da reação é marcado com biotina, o que permite sua detecção utilizando-se Strepavidina conjugada à Ficoeritrina-R. O produto da reação é então desnaturado, permitindo a hibridização a sondas de DNA complementar conjugados às microesferas codificadas flourescentemente. Um analizador de fluxo, LABScan ${ }^{\mathrm{TM}} 100$ (One Lambda, 
INC - Canoga Park, Califórnia, EUA), identifica a intensidade de fluorescência da ficoeritrina de cada microesfera. A indicação da tipagem do HLA é baseada no padrão de resultado da reação encontrado comparado pelo programa LABType TMSSO Analysis Software for Windows a padrões associados a sequências de genes HLA publicados ${ }^{(92)}$ os quais são atualizados semanalmente e disponibilizados online ${ }^{(93)}$.

\subsubsection{ANÁLISE ESTATÍSTICA}

Os dados coletados foram armazenados em um banco de dados e analisados utilizando-se o software SPSS for Mac versão 16.0 (SPSS Inc Chicago, Ilinois, EUA). As frequências alélicas dos genes HLA classes I e II foram determinadas por contagem direta. Para detecção de desvios significantes na frequência alélica dos pacientes em relação aos controles foi utilizado o teste exato de Fisher bicaudal. Foram consideradas diferenças estatisticamente significantes quando os valores de $P$ foram menores ou iguais a 0,05. As associações foram calculadas utilizando-se uma tabela de análise de contingência $2 \times 2^{(94)}$.

Os testes de associação genética foram realizados com correção para múltiplos testes ${ }^{(95)}$. Após a identificação dos alelos que apresentaram desvio 
significativo de frequência em pacientes com pênfigo vulgar em relação aos controles no teste exato de Fisher, uma correção para múltiplos testes foi realizada utilizando o método de Taxa de Descobertas Falsas (FDR - da Língua Inglesa, False Discovery Rate) ${ }^{(96)}$. Um total de 50 alelos HLA classes I e II foram identificados em pacientes com PV. O método é aplicado da seguinte maneira: iniciando do menor valor de $P\left(P_{i}\right)$, compare cada $P_{i}$ com $h_{(i)}=$ mínimo entre $\left[0,05\right.$ e $\left.0,05 \times m /(m+1-i)^{2}\right]$, onde $m$ é o número de testes realizados $(\mathrm{m}=$ 50). A hipótese de nulidade para $P_{i}$ será rejeitada enquanto este for igual ou menor que o limiar $h_{(i))}$ só parando quando $P_{(k)}>h_{(k)}$ pela primeira vez. Rejeitam-se todas as hipóteses de nulidade correspondentes ao menor $k-1$ valor de $P^{(97)}$.

As razões de chances (odds ratios) foram calculadas pelo método de Woolf, utilizando-se a fórmula $(\mathrm{a} \times \mathrm{d}) /(\mathrm{b} \times \mathrm{c})$, e expressas como risco relativo (RR) - com seus respectivos intervalos de confiança de 95\% (IC95\%) - por convenção ${ }^{(45)}$. Quando um elemento da equação foi igual a zero, para o cálculo do risco relativo foi utilizada a fórmula de Woolf modificada por Haldane: $[(2 \mathrm{a}+1)(2 \mathrm{~d}+1)] /[(2 \mathrm{~b}+1)(2 \mathrm{c}+1)]^{(98,99)}$.

Testes para verificação de desvios do equilíbrio de Hardy-Weinberg foram realizados utilizando o programa Arlequin 3.0 (Computational and Molecular Population Genetics Lab, Berna, Suíça) ${ }^{(100)}$.

Não houve necessidade de análise de frequências de haplótipos e de desequilíbrio de ligação uma vez que somente alelos do locus DRB1 estiveram associados à doença. 


\section{RESULTADOS}

Os dados referentes ao sexo e à cor da pele dos 36 pacientes e dos 712 controles incluídos no estudo estão apresentados na tabela 3. A média de idade do grupo de pacientes no momento do diagnóstico do PV foi de 40,3 anos com desvio padrão de 16,8. A tabela 4 apresenta a distribuição destes pacientes de acordo com a faixa etária. Não haviam dados disponíveis referente às idades dos indivíduos do grupo controle. 
Tabela 3 - Distribuição de acordo com sexo e cor da pele dos indivíduos incluídos no estudo

\begin{tabular}{|c|c|c|c|}
\hline PV & Controle & & Total \\
\hline$(n=36)$ & $(n=712)$ & $\mathbf{P}$ & $(n=743)$ \\
\hline \multirow[t]{2}{*}{$8(22,2 \%)$} & $373(52,4 \%)$ & & $381(50,9 \%)$ \\
\hline & & $<0,001$ & \\
\hline $28(77,8 \%)$ & $339(47,6 \%)$ & & $367(49,1 \%)$ \\
\hline
\end{tabular}

\section{Cor da Pele}

\begin{tabular}{|c|c|c|c|c|}
\hline Branca & $20(55,6 \%)$ & $507(71,2 \%)$ & & $527(70,5 \%)$ \\
\hline Negra & $2(5,6 \%)$ & $70(9,8 \%)$ & & $72(9,6 \%)$ \\
\hline Parda & $14(38,9 \%)$ & $124(17,4 \%)$ & 0,012 & $138(18,4 \%)$ \\
\hline Oriental & $0(0,0 \%)$ & $11(1,5 \%)$ & & $11(1,5 \%)$ \\
\hline Índio & $0(0,0 \%)$ & $0(0,0 \%)$ & & $0(0,0 \%)$ \\
\hline
\end{tabular}

Dados apresentados como n (\%)

PV = Pênfigo vulgar 
Tabela 4 - Distribuição de acordo com a faixa etária no momento do diagnóstico dos pacientes com $\mathrm{PV}$

\begin{tabular}{lr}
\hline Idade no diagnóstico de PV & $40,3 \pm 16,8$ \\
$<20$ anos & $4(11,1 \%)$ \\
$\geq 20$ e $<40$ anos & $13(36,1 \%)$ \\
$\geq 40$ e $<60$ anos & $14(38,9 \%)$ \\
$\geq 60$ anos & $5(13,9 \%)$
\end{tabular}

Dados apresentados como média \pm desvio padrão ou n (\%) $\mathrm{PV}=$ Pênfigo vulgar 
Os sintomas otorrinolaringológicos do PV e suas respectivas prevalências nos indivíduos estudados estão apresentados na tabela 5. Dos 36 pacientes avaliados, apenas $4(11,1 \%)$ estavam em remissão da doença, definida como ausência de evidência de doença há 6 meses ou mais sem o uso de medicações imunossupressoras sistêmicas, conforme critério proposto por Herbst e Bystryn ${ }^{(101)}$. A maioria dos indivíduos apresentavam lesões em cavidade oral $(83,4 \%)$ e pele $(69,5 \%)$. As prevalências dos outros sítios de apresentação das lesões estão descritas na tabela 6 . 
Tabela 5 - Prevalência de sintomas otorrinolaringológicos nos 36 pacientes com Pênfigo Vulgar

Sintomas Otorrinolaringológicos ${ }^{\mathrm{a}}$
Disfagia
$31(86,1 \%)$
Odinofagia
$31(86,1 \%)$
Rinorréia Sanguinolenta
$26(72,2 \%)$
Globus faríngeo
$24(66,7 \%)$
Crostas nasais
$23(63,9 \%)$
Disfonia
$22(61,1 \%)$
Obstrução nasal
$17(47,2 \%)$
Epistaxe
$17(47,2 \%)$

a: Em qualquer momento da doença 
Tabela 6 - Frequência de acometimento pelo Pênfigo Vulgar dos diferentes órgãos e regiões anatômicas nos 36 pacientes estudados

Locais das lesões

Boca

Pele

Genitais

Conjuntiva

Cavidade nasal

Faringe

Laringe
$30(83,4 \%)$

$25(69,5 \%)$

$9(25,0 \%)$

$10(27,8 \%)$

$23(63,9 \%)$

$24(66,7 \%)$

$22(61,1 \%)$

c: A partir de história, exame físico, endoscopia nasal e laríngea 
A distribuição dos genótipos nos loci A, B e DR não apresentaram desvios do equilíbrio de Hardy-Weinberg para o grupo PV $(p=0,41, p=0,43$ e $p=0,83$, respectivamente) ou controles $(p=0,11, p=0,14$ e $p=0,13$, respectivamente). A apresentação completa dos resultados dos testes de EHW estão reproduzidas no anexo $\mathrm{E}$.

As prevalências fenotípicas dos alelos HLA encontradas nos pacientes com PV e no grupo controle para os loci A, B e DR estão apresentadas respectivamente nas tabelas 7, 8 e 9 e nas figuras 8, 9 e 10. Após correção para múltiplos testes, não houve associação estatisticamente significante entre PV e nenhum alelo dos loci A ou B. Para o locus DR, no entanto, os alelos DRB1*04, DRB1*08 e DRB1*14 apresentaram associação estatisticamente significante, com RR de 5,5 (IC95\%: 2,8 - 11,0) ( $p=0,000001)$, 4,7 (IC95\%: $2,3-9,5)(p=0,000066)$ e 4,8 (IC95\%:2,2 - 10,4) ( $p=0,000389)$, respectivamente. 
Tabela 7 - Prevalência fenotípica de cada alelo HLA locus A nos indivíduos estudados.

\begin{tabular}{|c|c|c|c|c|}
\hline \multirow[b]{2}{*}{ HLA } & \multicolumn{2}{|c|}{ Grupo } & \multirow[b]{2}{*}{$\mathbf{P}$} & \multirow[b]{2}{*}{ RR (IC95\%) } \\
\hline & $\begin{array}{c}\text { PV } \\
(n=36)\end{array}$ & $\begin{array}{l}\text { Controle } \\
(n=712)\end{array}$ & & \\
\hline A01 & $7(19,4 \%)$ & $125(17,6 \%)$ & 0,82 & $1,1(0,5-2,6)$ \\
\hline A02 & $13(36,1 \%)$ & $305(42,8 \%)$ & 0,49 & $0,8(0,4-1,5)$ \\
\hline A03 & $4(11,1 \%)$ & $115(16,2 \%)$ & 0,64 & $0,7(0,2-1,9)$ \\
\hline A11 & $4(11,1 \%)$ & $86(12,1 \%)$ & 1,0 & $0,9(0,3-2,6)$ \\
\hline A23 & $3(8,3 \%)$ & $78(11,0 \%)$ & 0,78 & $0,7(0,2-2,5)$ \\
\hline A24 & $8(22,2 \%)$ & $134(18,8 \%)$ & 0,66 & $1,2(0,5-2,8)$ \\
\hline A25 & $1(2,8 \%)$ & $18(2,5 \%)$ & 0,61 & $1,1(0,1-8,5)$ \\
\hline A26 & $3(8,3 \%)$ & $42(5,9 \%)$ & 0,47 & $1,5(0,4-4,9)$ \\
\hline A29 & $3(8,3 \%)$ & $57(8,0 \%)$ & 1,0 & $1,0(0,3-3,5)$ \\
\hline A30 & $2(5,6 \%)$ & $88(12,4 \%)$ & 0,29 & $0,4(0,1-1,8)$ \\
\hline A31 & $3(8,3 \%)$ & $56(7,9 \%)$ & 0,76 & $1,1(0,3-3,6)$ \\
\hline A32 & $4(11,1 \%)$ & $31(4,4 \%)$ & 0,081 & $2,7(0,9-8,2)$ \\
\hline A33 & $4(11,1 \%)$ & $35(4,9 \%)$ & 0,11 & $2,4(0,8-7,2)$ \\
\hline A36 & $1(2,8 \%)$ & $17(2,4 \%)$ & 0,59 & $1,2(0,2-9,0)$ \\
\hline A66 & $3(8,3 \%)$ & $17(2,4 \%)$ & 0,066 & $3,7(1,0-13,3)$ \\
\hline A68 & $6(16,7 \%)$ & $101(14,2 \%)$ & 0,63 & $1,2(0,5-3,0)$ \\
\hline
\end{tabular}

Dados apresentados como n (\%).

PV = Pênfigo Vulgar; RR = Risco Relativo; IC = Intervalo de confiança. 


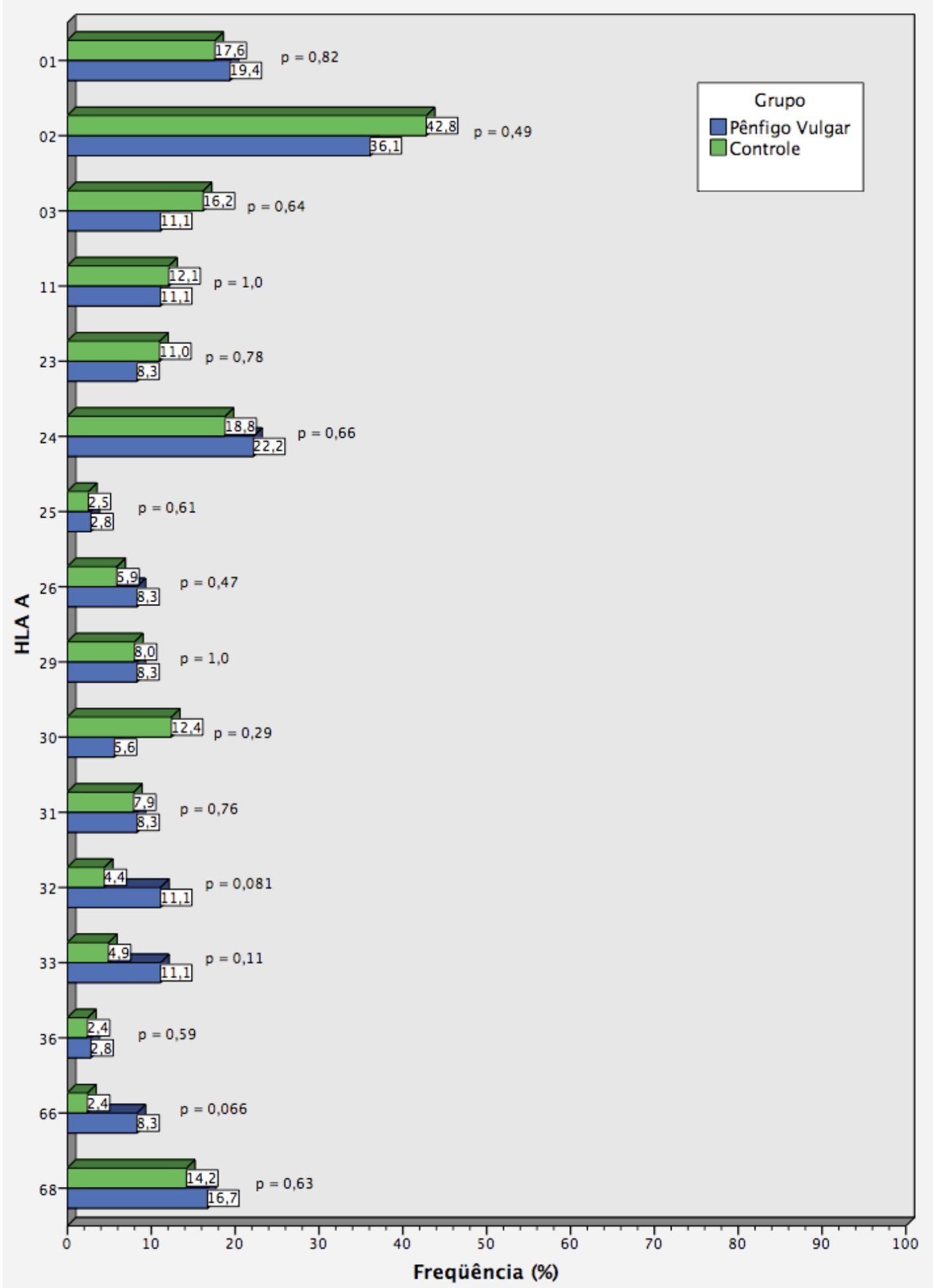

Figura 8: Prevalência fenotípica de cada alelo HLA locus A nos indivíduos estudados de acordo com o grupo. 
Tabela 8 - Prevalência de cada alelo HLA locus B nos indivíduos estudados.

\section{Grupo}

HLA

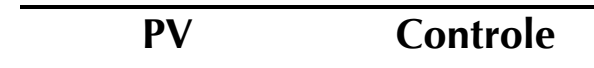

$(\mathrm{n}=36) \quad(\mathrm{n}=712)$

P $\quad$ RR (IC95\%)

\begin{tabular}{|c|c|c|c|c|}
\hline B07 & $1(2,8 \%)$ & $97(13,6 \%)$ & 0,07 & $0,2(0,03-1,3)$ \\
\hline B08 & $2(5,6 \%)$ & $63(8,8 \%)$ & 0,76 & $0,6(0,1-2,6)$ \\
\hline B14 & $4(11,1 \%)$ & $71(10,0 \%)$ & 0,78 & $1,1(0,4-3,3)$ \\
\hline B15 & $1(2,8 \%)$ & $120(16,9 \%)$ & 0,019 & $0,1(0,02-1,0)$ \\
\hline B18 & $1(2,8 \%)$ & $80(11,2 \%)$ & 0,16 & $0,2(0,03-1,7)$ \\
\hline B35 & $8(22,2 \%)$ & $172(24,2 \%)$ & 1,0 & $0,9(0,4-2,0)$ \\
\hline B37 & $1(2,8 \%)$ & $18(2,5 \%)$ & 0,61 & $1,1(0,1-8,5)$ \\
\hline B38 & $2(5,6 \%)$ & $31(4,4 \%)$ & 0,67 & $1,3(0,3-5,6)$ \\
\hline B39 & $3(8,3 \%)$ & $43(6,0 \%)$ & 0,48 & $1,4(0,4-4,8)$ \\
\hline B40 & $1(2,8 \%)$ & $57(8,0 \%)$ & 0,35 & $0,3(0,04-2,4)$ \\
\hline B42 & $3(8,3 \%)$ & $18(2,5 \%)$ & 0,075 & $3,5(1,0-12,5)$ \\
\hline B44 & $8(22,2 \%)$ & $135(19,0 \%)$ & 0,66 & $1,2(0,5-2,7)$ \\
\hline B45 & $2(5,6 \%)$ & $24(3,4 \%)$ & 0,36 & $1,7(0,4-7,4)$ \\
\hline B48 & $2(5,6 \%)$ & $7(1,0 \%)$ & 0,066 & $5,9(1,2-29,6)$ \\
\hline B49 & $2(5,6 \%)$ & $34(4,8 \%)$ & 0,69 & $1,2(0,3-5,1)$ \\
\hline B50 & $2(5,6 \%)$ & $27(3,8 \%)$ & 0,64 & $1,5(0,3-6,5)$ \\
\hline B51 & $5(13,9 \%)$ & $112(15,7 \%)$ & 1,0 & $0,9(0,3-2,3)$ \\
\hline B53 & $7(19,4 \%)$ & $38(5,3 \%)$ & 0,004 & $4,3(1,8-10,4)$ \\
\hline B55 & $1(2,8 \%)$ & $17(2,4 \%)$ & 0,59 & $1,2(0,2-9,0)$ \\
\hline
\end{tabular}


Tabela 8 (conclusão) - Prevalência dos alelo HLA locus B nos indivíduos estudados.

\begin{tabular}{lccccc}
\hline & \multicolumn{3}{c}{ Grupo } & & \\
\cline { 2 - 4 } HLA & PV & Controle & & \\
& $(\mathbf{n}=\mathbf{3 6})$ & $(\mathbf{n}=7 \mathbf{1 2})$ & & $\mathbf{P}$ & RR $($ IC95 $\%)$ \\
\hline B57 & $7(19,4 \%)$ & $31(4,4 \%)$ & 0,002 & $5,3(2,2-13,0)$ \\
B58 & $3(8,3 \%)$ & $49(6,9 \%)$ & 0,73 & $1,2(0,4-4,2)$ \\
\hline
\end{tabular}

Dados apresentados como n (\%).

PV = Pênfigo Vulgar; RR = Risco Relativo; IC = Intervalo de confiança. 


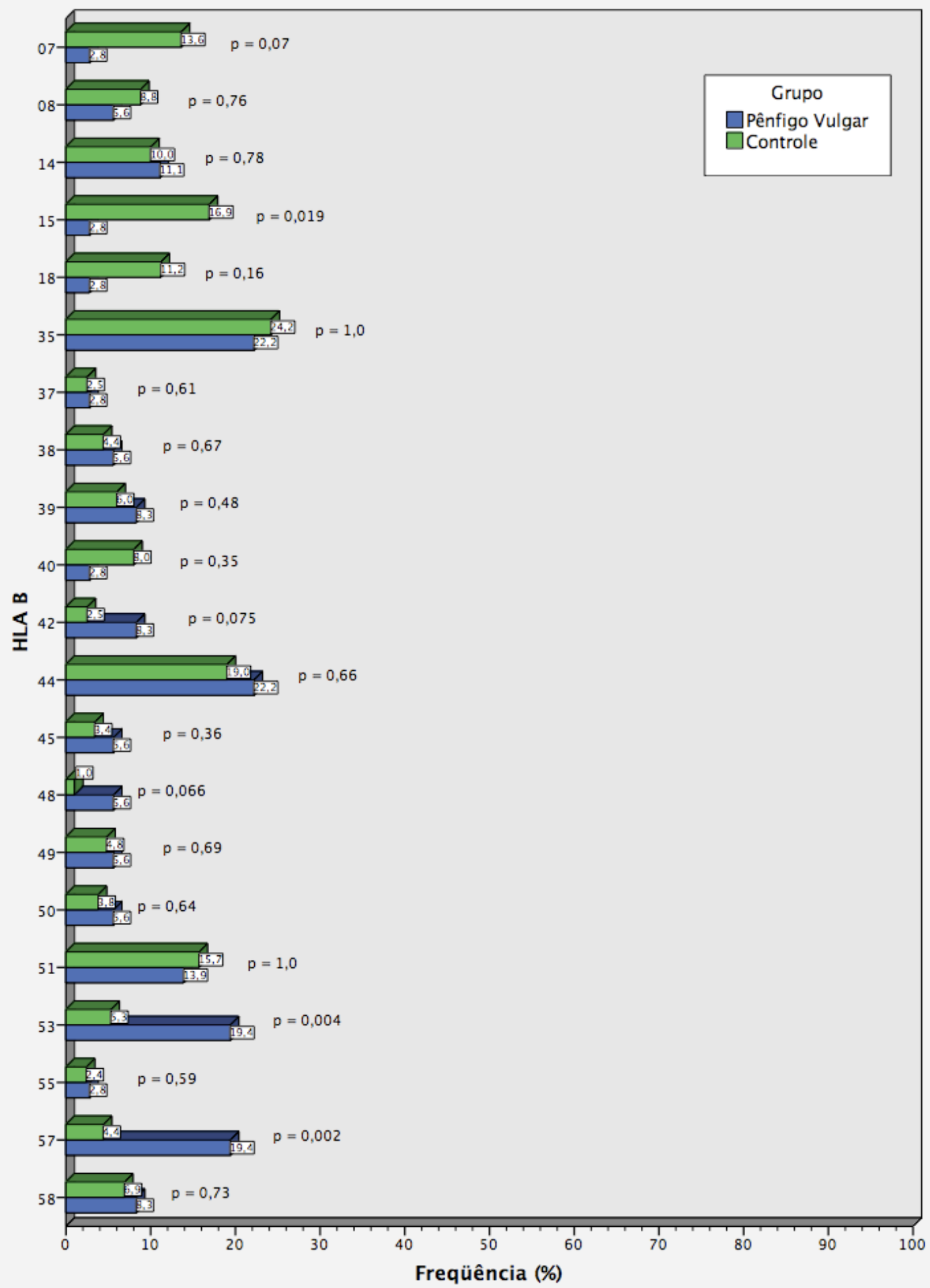

Figura 9: Prevalência de cada alelo HLA locus B nos indivíduos estudados de acordo com o grupo. 
Tabela 9 - Prevalência de cada alelo HLA locus DR nos indivíduos estudados.

\section{Grupo}

HLA

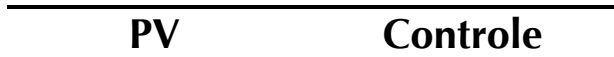

$$
\begin{array}{llll}
(n=36) & (n=712) & P & \text { RR }(I C 95 \%)
\end{array}
$$

\begin{tabular}{|c|c|c|c|c|}
\hline$\overline{\text { DRB1*01 }}$ & $3(8,3 \%)$ & $144(20,2 \%)$ & 0,087 & $0,4(0,1-1,2)$ \\
\hline DRB1*03 & $4(11,1 \%)$ & $134(18,8$ \%) & 0,37 & $0,5(0,2-1,6)$ \\
\hline DRB1*04 & $21(58,3 \%)$ & $144(20,2 \%)$ & $<0,001^{(1)}$ & $5,5(2,8-11,0)$ \\
\hline DRB1*07 & $5(13,9 \%)$ & $150(21,1 \%)$ & 0,4 & $0,6(0,2-1,6)$ \\
\hline DRB1*08 & $14(38,9 \%)$ & $85(11,9 \%)$ & $<0,001^{(1)}$ & $4,7(2,3-9,5)$ \\
\hline DRB1*09 & $1(2,8 \%)$ & $28(3,9 \%)$ & 1,0 & $0,7(0,1-5,3)$ \\
\hline DRB $1 * 10$ & $2(5,6 \%)$ & $26(3,7 \%)$ & 0,64 & $1,6(0,4-6,8)$ \\
\hline DRB1*11 & $6(16,7 \%)$ & $176(24,7 \%)$ & 0,32 & $0,6(0,2-1,5)$ \\
\hline DRB1*12 & $1(2,8 \%)$ & $23(3,2 \%)$ & 1,0 & $0,9(0,1-6,5)$ \\
\hline DRB1*13 & $2(5,6 \%)$ & $188(26,4$ \%) & 0,003 & $0,2(0,04-0,7)$ \\
\hline DRB1*14 & $10(27,8 \%)$ & $53(7,4 \%)$ & $<0,001^{(1)}$ & $4,8(2,2-10,4)$ \\
\hline DRB1*15 & $1(2,8 \%)$ & $133(18,7 \%)$ & 0,012 & $0,1(0,02-9,2)$ \\
\hline DRB1*16 & $1(2,8 \%)$ & $48(6,7 \%)$ & 0,5 & $0,5(0,1-3,0)$ \\
\hline
\end{tabular}

Dados apresentados como $\mathrm{n}(\%)$.

$\mathrm{PV}=$ Pênfigo Vulgar; RR = Risco Relativo; IC = Intervalo de confiança.

(1) Diferença estatisticamente significante após correção para múltiplos testes pelo método FDR $(\mathrm{p}<0,00113173)$. 


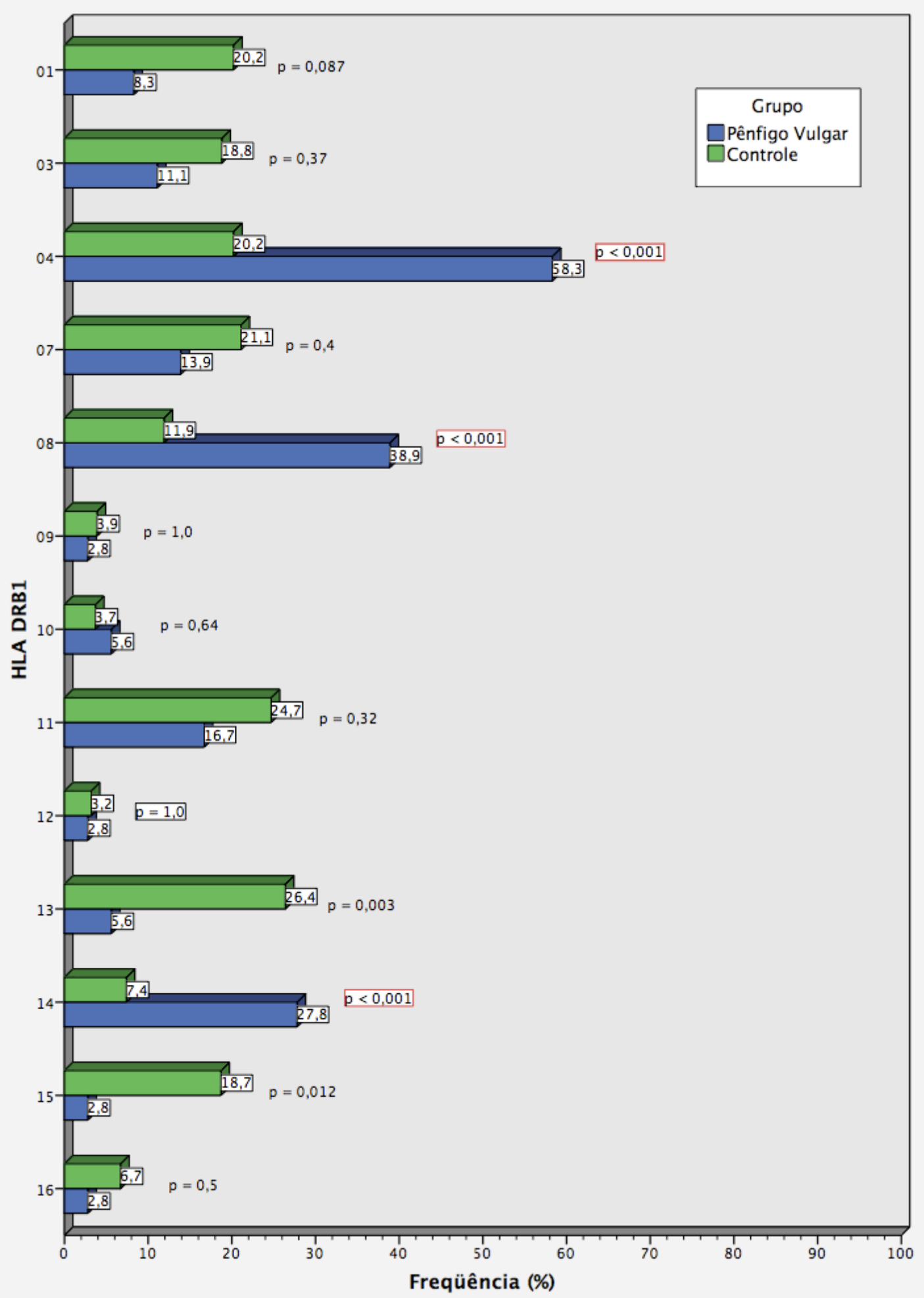

Figura 10: Prevalência de cada alelo HLA locus DR nos indivíduos estudados de acordo com o grupo. Os alelos 04,08 e 14 apresentaram diferença estatisticamente significante após correção para múltiplos testes pelo método FDR $(p<0,00113173)$. 
O painel de alelos de HLA-DRB1 dos 36 pacientes estudados está apresentado de acordo com a nomenclatura NMDP ${ }^{(93)}$ na tabela 10. A tabela 11 resume as diferenças significativas nas frequências de alelos do locus HLADRB1 entre casos e controles. 
Tabela 10 - Alelos do locus HLA-DRB1 dos 36 doentes com Pênfigo Vulgar de acordo com a nomenclatura NMDP

\begin{tabular}{|c|c|c|}
\hline Paciente & HLA-DRB1 & Possíveis subtipos \\
\hline \multirow[t]{2}{*}{1} & $01: 02$ & \\
\hline & 08:04 & \\
\hline \multirow[t]{2}{*}{2} & 01:02 & \\
\hline & 14DJGE & $01 / 54 / 60 / 75$ \\
\hline \multirow[t]{2}{*}{3} & 01DFXJ & 01/05/07/08/11/13/19 \\
\hline & 04:02 & \\
\hline \multirow[t]{2}{*}{4} & 03ATHX & $01 / 18 / 19 / 22 / 28$ \\
\hline & 04:02 & \\
\hline \multirow[t]{2}{*}{5} & 03ATTY & $01 / 13 / 18 / 19 / 22 / 28$ \\
\hline & 04:02 & \\
\hline \multirow[t]{2}{*}{6} & 03ATUA & 01/06/13/18/19/22/28 \\
\hline & 08AXN & $04 / 29$ \\
\hline \multirow[t]{2}{*}{7} & 03DGMC & 01/13/18/19/22/28/37 \\
\hline & $04: 32$ & \\
\hline \multirow[t]{2}{*}{8} & 04:02 & \\
\hline & 04BBRR & $06 / 46 / 49$ \\
\hline \multirow[t]{2}{*}{9} & 04:02 & \\
\hline & 07CDPZ & 01/03/05/07/09/10N/11 \\
\hline \multirow[t]{2}{*}{10} & 04:02 & \\
\hline & 07CDPZ & 01/03/05/07/09/10N/11 \\
\hline \multirow[t]{2}{*}{11} & 04:02 & \\
\hline & 07CDPZ & 01/03/05/07/09/10N/11 \\
\hline \multirow[t]{2}{*}{12} & 04:02 & \\
\hline & 08:06 & \\
\hline \multirow[t]{2}{*}{13} & 04:02 & \\
\hline & 10:01 & \\
\hline
\end{tabular}


Tabela 10 (continuação) - Alelos do locus HLA-DRB1 dos 36 doentes com Pênfigo Vulgar de acordo com a nomenclatura NMDP

\begin{tabular}{|c|c|c|}
\hline Paciente & HLA-DRB1 & Possíveis subtipos \\
\hline \multirow[t]{2}{*}{14} & 04:02 & \\
\hline & 11APWP & $01 / 12 / 15 / 24 / 27 / 28 / 29 / 39 / 49$ \\
\hline \multirow[t]{2}{*}{15} & 04:02 & \\
\hline & 11APWP & 01/12/15/24/27/28/29/39/49 \\
\hline \multirow[t]{2}{*}{16} & 04:02 & \\
\hline & 11ARAP & $04 / 43 / 44$ \\
\hline \multirow[t]{2}{*}{17} & 04:02 & \\
\hline & 12BACJ & 01/06/08/10 \\
\hline \multirow[t]{2}{*}{18} & 04:02 & \\
\hline & 14CDTG & $01 / 26 / 54 / 60$ \\
\hline \multirow[t]{2}{*}{19} & 04:02 & \\
\hline & 14CDTG & $01 / 26 / 54 / 60$ \\
\hline \multirow[t]{2}{*}{20} & 04:02 & \\
\hline & $14 \mathrm{WHG}$ & $02 / 47$ \\
\hline \multirow[t]{2}{*}{21} & 04:02 & \\
\hline & 15CDTE & $01 / 13 / 16 / 20 / 22$ \\
\hline \multirow[t]{2}{*}{22} & 04:02 & \\
\hline & 16:02 & \\
\hline \multirow[t]{2}{*}{23} & 04:11 & \\
\hline & 08:04 & \\
\hline \multirow[t]{2}{*}{24} & 04:11 & \\
\hline & 08:04 & \\
\hline \multirow[t]{2}{*}{25} & 04BK & $02 / 14$ \\
\hline & 13CJYJ & 01/02/28/39/59/61/69/73 \\
\hline
\end{tabular}


Tabela 10 (conclusão) - Alelos do locus HLA-DRB1 dos 36 doentes com Pênfigo Vulgar de acordo com a nomenclatura NMDP

\begin{tabular}{|c|c|c|}
\hline Paciente & HLA-DRB1 & Possíveis subtipos \\
\hline \multirow[t]{2}{*}{26} & 07CDPZ & 01/03/05/07/09/10N/11 \\
\hline & 08:04 & \\
\hline \multirow[t]{2}{*}{27} & 07DFYE & 01/03/05/07/08/09/10N/11/14/15 \\
\hline & 14DFYX & $01 / 54 / 58 / 60 / 75$ \\
\hline \multirow[t]{2}{*}{28} & 08:04 & \\
\hline & 10:01 & \\
\hline \multirow[t]{2}{*}{29} & 08:04 & \\
\hline & 11:02 & \\
\hline \multirow[t]{2}{*}{30} & 08:04 & \\
\hline & 11APWP & 01/12/15/24/27/28/29/39/49 \\
\hline \multirow[t]{2}{*}{31} & 08:04 & \\
\hline & 11APWP & 01/12/15/24/27/28/29/39/49 \\
\hline \multirow[t]{2}{*}{32} & 08:04 & \\
\hline & 14AYWB & $02 / 41 / 47$ \\
\hline \multirow[t]{2}{*}{33} & 08:04 & \\
\hline & 14CDTG & $01 / 26 / 54 / 60$ \\
\hline \multirow[t]{2}{*}{34} & 08:04 & \\
\hline & 14DHHZ & $01 / 26 / 54 / 60 / 70 / 75$ \\
\hline \multirow[t]{2}{*}{35} & 08:04 & \\
\hline & 14DHHZ & $01 / 26 / 54 / 60 / 70 / 75$ \\
\hline \multirow[t]{2}{*}{36} & 13CAXA & $02 / 73$ \\
\hline & 14:04 & \\
\hline
\end{tabular}


Tabela 11 - Prevalência em casos e controles dos alelos HLA-DRB1 associados ao Pênfigo Vulgar

\begin{tabular}{|c|c|c|c|c|}
\hline \multirow[b]{2}{*}{ HLA } & \multicolumn{2}{|c|}{ Grupo } & \multirow[b]{2}{*}{$\mathbf{P}$} & \multirow[b]{2}{*}{ RR (IC95\%) } \\
\hline & $\begin{array}{c}\text { PV } \\
(n=36)\end{array}$ & $\begin{array}{l}\text { Controle } \\
(\mathbf{n}=712)\end{array}$ & & \\
\hline DRB1*04:02 & $17(47,2 \%)$ & $14(2,0 \%)$ & $<0,001^{(1)}$ & $44,6(19,2-103)$ \\
\hline DRB1*08:04 & $13(36,1 \%)$ & $21(2,9 \%)$ & $<0,001^{(1)}$ & $18,6(8,3-41,7)$ \\
\hline DRB1*14 & $10(27,8 \%)$ & $53(7,4 \%)$ & $<0,001^{(2)}$ & $4,8(2,2-10,4)$ \\
\hline
\end{tabular}

A tabela 12 apresenta as prevalências dos alelos HLA-DRB1 em casos e controles estratificada de acordo com a cor da pele dos indivíduos. 
Tabela 12 - Prevalência dos alelos HLA locus DR nos indivíduos estudados estratificados de acordo com a cor da pele

\begin{tabular}{|c|c|c|c|c|c|}
\hline \multirow[b]{2}{*}{ HLA } & \multirow[b]{2}{*}{ Cor da Pele } & \multicolumn{2}{|c|}{ Grupo } & \multirow[b]{2}{*}{$\mathbf{P}$} & \multirow[b]{2}{*}{ RR (IC95\%) } \\
\hline & & PV & Controle & & \\
\hline & Branca & $(n=20)$ & $(n=507)$ & & \\
\hline & Negra & $(n=2)$ & $(\mathrm{n}=70)$ & & \\
\hline & Parda & $(n=14)$ & $\mathrm{n}=124$ & & \\
\hline \multirow[t]{3}{*}{ DRB1*01 } & Branca & $3(15,0 \%)$ & $108(21,3 \%)$ & 0,78 & $0,7(0,2-2,3)$ \\
\hline & Negra & $0(0,0 \%)$ & $12(17,1 \%)$ & 1,0 & $1,5(0,1-15,7)$ \\
\hline & Parda & $0(0,0 \%)$ & $23(18,5 \%)$ & 0,13 & $0,3(0,04-2,3)$ \\
\hline \multirow[t]{3}{*}{ DRB $1 * 03$} & Branca & $1(5,0 \%)$ & 95 (18,7 \%) & 0,15 & $0,2(0,1-1,7)$ \\
\hline & Negra & $0(0,0 \%)$ & $14(20,0 \%)$ & 1,0 & $1,3(0,1-13)$ \\
\hline & Parda & $3(21,4 \%)$ & $25(20,2 \%)$ & 1,0 & $1,1(0,3-4,2)$ \\
\hline \multirow[t]{3}{*}{ DRB $1 * 04$} & Branca & $14(70,0 \%)$ & $105(20,7 \%)$ & $<0,001^{(1)}$ & $8,9(3,4-23,8)$ \\
\hline & Negra & $0(0,0 \%)$ & $11(15,7 \%)$ & 1,0 & $1,7(0,2-17,0)$ \\
\hline & Parda & $7(50,0 \%)$ & $25(20,2 \%)$ & 0,02 & $4,0(1,3-12,3)$ \\
\hline \multirow[t]{3}{*}{ DRB1*04:02 } & Branca & $14(70,0 \%)$ & $10(2,0 \%)$ & $<0,001^{(2)}$ & $116(37-364)$ \\
\hline & Negra & $0(0,0 \%)$ & $3(4,3 \%)$ & 1,0 & $5,7(0,5-67,5)$ \\
\hline & Parda & $3(21,4 \%)$ & $1(0,8 \%)$ & 0,003 & $33,5(3,2-350)$ \\
\hline \multirow[t]{3}{*}{ DRB1*07 } & Branca & $5(25,0 \%)$ & $114(22,5 \%)$ & 0,79 & $1,1(0,4-3,2)$ \\
\hline & Negra & $0(0,0 \%)$ & $12(17,1 \%)$ & 1,0 & $1,5(0,1-15,7)$ \\
\hline & Parda & $0(0,0 \%)$ & $23(18,5 \%)$ & 0,13 & $0,3(0,04-2,3)$ \\
\hline \multirow[t]{3}{*}{ DRB1*08 } & Branca & $5(25,0 \%)$ & $58(11,4 \%)$ & 0,08 & $2,6(0,9-7,4)$ \\
\hline & Negra & $2(100 \%)$ & $11(15,7 \%)$ & 0,03 & $15(1,4-156)$ \\
\hline & Parda & $7(50,0 \%)$ & $15(12,1 \%)$ & 0,002 & $7,3(2,2-23,6)$ \\
\hline \multirow[t]{3}{*}{ DRB1*08:04 } & Branca & $4(20,0 \%)$ & $12(2,4 \%)$ & 0,002 & $10,3(3,0-35,5)$ \\
\hline & Negra & $2(100 \%)$ & $5(7,1 \%)$ & 0,008 & $32,5(2,9-363)$ \\
\hline & Parda & $7(50,0 \%)$ & $4(3,2 \%)$ & $<0,001^{(3)}$ & $30,0(7,1-127)$ \\
\hline \multirow[t]{3}{*}{ DRB $1 * 09$} & Branca & $0(0,0 \%)$ & $19(3,7 \%)$ & 1,0 & $1,16(0,2-9,1)$ \\
\hline & Negra & $0(0,0 \%)$ & $2(2,9 \%)$ & 1,0 & $7,7(0,6-97,3)$ \\
\hline & Parda & $1(7,1 \%)$ & $3(2,4 \%)$ & 0,35 & $3,1(0,3-32,0)$ \\
\hline
\end{tabular}

PV = Pênfigo Vulgar; RR = Risco Relativo

${ }^{(1)} p=0,000005 ;{ }^{(2)} p<0,000001 ;{ }^{(3)} p=0,000006$ 
Tabela 12 (conclusão) - Prevalência dos alelos HLA locus DR nos indivíduos estudados estratificados de acordo com a cor da pele

\begin{tabular}{|c|c|c|c|c|c|}
\hline \multirow[b]{2}{*}{ HLA } & \multirow[b]{2}{*}{ Cor da Pele } & \multicolumn{2}{|c|}{ Grupo } & \multirow[b]{2}{*}{$\mathbf{P}$} & \multirow[b]{2}{*}{ RR (IC95\%) } \\
\hline & & $\mathbf{P V}$ & Controle & & \\
\hline & Branca & $(\mathrm{n}=20)$ & $(n=507)$ & & \\
\hline & Negra & $(\mathrm{n}=2)$ & $(\mathrm{n}=70)$ & & \\
\hline & Parda & $(n=14)$ & $n=124$ & & \\
\hline \multirow[t]{3}{*}{ DRB1*10 } & Branca & $2(10,0 \%)$ & $17(3,4 \%)$ & 0,16 & $3,2(0,7-14,9)$ \\
\hline & Negra & $0(0,0 \%)$ & $2(2,9 \%)$ & 1,0 & $7,7(0,6-97,3)$ \\
\hline & Parda & $0(0,0 \%)$ & $7(5,6 \%)$ & 1,0 & $1,0(0,1-8,4)$ \\
\hline \multirow[t]{3}{*}{ DRB1*11 } & Branca & $2(10,0 \%)$ & $123(24,3 \%)$ & 0,18 & $0,3(0,1-1,5)$ \\
\hline & Negra & $1(50,0 \%)$ & $19(27,1 \%)$ & 0,48 & $2,7(0,2-45,0)$ \\
\hline & Parda & $3(21,4 \%)$ & $(32(25,8 \%)$ & 1,0 & $0,8(0,2-3,0)$ \\
\hline \multirow[t]{3}{*}{ DRB1*12 } & Branca & $0(0,0 \%)$ & $12(2,4 \%)$ & 1,0 & $1,8(0,2-14,5)$ \\
\hline & Negra & $0(0,0 \%)$ & $4(5,7 \%)$ & 1,0 & $4,5(0,4-51,2)$ \\
\hline & Parda & $1(7,1 \%)$ & $7(5,6 \%)$ & 0,59 & $1,3(1,5-11,3)$ \\
\hline \multirow[t]{3}{*}{ DRB1*13 } & Branca & $0(0,0 \%)$ & $133(26,2 \%)$ & 0,003 & $0,1(0,02-1,0)$ \\
\hline & Negra & $0(0,0 \%)$ & $22(31,4 \%)$ & 1,0 & $0,7(0,1-7,2)$ \\
\hline & Parda & $2(14,3 \%)$ & $31(25,0 \%)$ & 0,52 & $0,5(0,1-2,4)$ \\
\hline \multirow[t]{3}{*}{ DRB1*14 } & Branca & $6(30,0 \%)$ & $40(7,9 \%)$ & 0,005 & $5,0(1,8-13,7)$ \\
\hline & Negra & $1(50,0 \%)$ & $3(4,3 \%)$ & 0,1 & $22,3(1,1-450)$ \\
\hline & Parda & $3(21,4 \%)$ & $9(7,3 \%)$ & 0,11 & $3,5(0,8-14,8)$ \\
\hline \multirow[t]{3}{*}{ DRB1*15 } & Branca & $1(5,0 \%)$ & $94(18,5 \%)$ & 0,15 & $0,2(0,03-1,7)$ \\
\hline & Negra & $0(0,0 \%)$ & $14(20,0 \%)$ & 1,0 & $1,3(0,1-13)$ \\
\hline & Parda & $0(0,0 \%)$ & $22(17,7 \%)$ & 0,13 & $0,3(0,04-2,4)$ \\
\hline \multirow[t]{3}{*}{ DRB1*16 } & Branca & $1(5,0 \%)$ & $35(6,9 \%)$ & 1,0 & $0,7(0,1-5,5)$ \\
\hline & Negra & $0(0,0 \%)$ & $1(1,4 \%)$ & 1,0 & $11,7(0,8-167)$ \\
\hline & Parda & $0(0,0 \%)$ & $12(9,7 \%)$ & 0,6 & $0,6(0,1-4,8)$ \\
\hline
\end{tabular}

PV = Pênfigo Vulgar; RR = Risco Relativo 


\section{DISCUSSÃO}

O Pênfigo Vulgar é uma doença de grande morbidade. Os principais sintomas observados foram a dificuldade e a dor à deglutição, presentes em 86\% dos pacientes estudados, consequência de lesões ao longo da cavidade oral e da faringe. Langan e colaboradores ${ }^{(59)}$ relatam que a mortalidade de portadores de PV dentro de um ano no Reino Unido é de 12\% (8 a 19\%) apresentando razão de risco (hazard ratio) em relação aos controles de 2,8 (1,9 a 4,3). Uma vez que a fisiopatogenia completa da doença não é conhecida, principalmente quanto aos fatores desencadeadores da doença, os tratamentos hoje disponíveis baseiam-se na imunossupressão, com consequente diminuição da agressão autoimune. Embora isoladamente o PV seja uma doença rara, é provável que compartilhe mecanismos fisiopatológicos com outras doenças autoimunes. A descoberta desses mecanismos pode levar a avanços no diagnóstico ou à capacidade de uso de agentes terapêuticos mais eficientes e com menores riscos de efeitos adversos, beneficiando pacientes com PV e outras doenças autoimunes.

Dentre os diversos alelos já relatados como associados ao PV (tabelas 1 e 2), somente o alelo DRB $1 * 04: 02$ tem mecanismo proposto para a gênese da autoimunidade no PV ${ }^{(80)}$. A expectativa do presente estudo, pesquisando a associação de alelos do sistema HLA na população brasileira, não era de encontrar alelos diferentes dos já descritos, e sim, em função das particularidades dessa população e dos novos conhecimentos metodológicos, 
acrescentar evidências que ajudem a identificar quais são os alelos verdadeiramente associados à genese da doença. Sendo o PV uma doença de causas evidentemente multifatoriais e poligênica, mais estudos em pacientes negativos para o DRB1*04:02 são necessários para identificar outros fatores genéticos relacionados ou não ao HLA presumivelmente envolvidos na sua patogênese $^{(49)}$.

$\mathrm{Li}^{(50)}$ afirma que, quando um grande número de diferentes alelos estão associados a uma doença, são necessárias replicações de estudos em diferentes populações para identificar quais as variantes que realmente conferem risco à doença, possibilitando também a estimativa do risco atribuível na população, dos níveis de penetrância ou de fatores modificadores ainda não caracterizados. A identificação destes loci do HLA de susceptibilidade à doença é requisito para a compreensão da autoimunidade mediada pelo complexo principal de histocompatibilidade e pode facilitar a formulação de terapias antígeno-específicas. A identificação dos loci de susceptibilidade, porém, depende de genotipagem HLA continuada de pacientes e controles ${ }^{(45)}$. 


\subsection{Desenho do estudo e composição dos grupos de casos e controles}

A opção por um desenho do tipo caso-controle para a realização do estudo foi justificada pela baixa prevalência de PV na população. Estudos de coorte têm como vantagem a capacidade de estimarem de maneira mais fidedigna os riscos relativos conferidos pelas condições em estudo ${ }^{(50)}$, porém para o seguimento de um número suficiente de casos seriam necessárias coortes com número de indivíduos estimados em milhões, o que tornam tais situações impraticáveis tendo em vista as limitações de custo e de tempo. Estudos caso-controle são reconhecidamente convenientes para a localização dos loci de susceptibilidade às doenças e são mais poderosos que estudos baseados em análise de segregação familiar para a detecção de efeitos genéticos fracos ${ }^{(102)}$. Existem importantes vantagens do uso do desenho casocontrole em estudos de associação genética: sua metodologia é bem compreendida; amostras bastante grandes podem ser recrutadas de casos e controles de maneira mais conveniente e eficiente do que de famílias; doenças de início tardio podem ser estudadas; frequência dos alelos, penetrância e risco atribuível podem ser simultaneamente estimados; maior poder do estudo ao utilizar controles não consanguíneos ${ }^{(102)}$.

No presente estudo, o grupo de casos foi constituído de 36 pacientes com diagnóstico confirmado de PV que estavam em acompanhamento ambulatorial, e o grupo controle de 712 indivíduos doadores voluntários de 
medula óssea. Embora os grupos tenham apresentado prevalências de gênero com diferenças significativas entre si (grupo em estudo com maior prevalência de mulheres), essa diferença é irrelevante em relação aos resultados encontrados. O PV não é uma doença que apresenta padrão de herança associada aos cromossomos sexuais, e o sistema HLA está situado no cromossomo 6, não havendo qualquer interdependência na segregação entre eles. Apesar de controverso se a incidência de PV difere entre homens e mulheres, confiamos na estimativa do estudo de coorte de Langan e colaboradores ${ }^{(59)}$ que, incluindo 380 pacientes-ano e 1.763 controles-ano, observou razão de incidência homem/mulher de 1,0/1,5, com intervalo de confiança calculado entre 1,0/1,1 a 1,0/2,2. A maior incidência de PV no sexo feminino, também observada no presente estudo, é uma situação comum a diversas doenças autoimunes: síndrome de Sjögren, Lúpus Eritematoso Sistêmico, tireoidite auto-imune, Miastenia Gravis e Artrite Reumatóide ${ }^{(103)}$. Uma vez que um modelo multifatorial é sugerido para a gênese das doenças auto-imunes ${ }^{(103)}$, os hormônios sexuais e outros fatores neuroendócrinos, atuando de maneira diferente na apresentação de antígenos, na ativação de linfócitos, na expressão de citocinas ou no direcionamento de células de imunes, modulariam a resposta imune também de maneiras diferentes entre os sexos, explicando a diferença observada.

A importância de não serem recrutados no grupo em estudo mais que um paciente de uma determinada família é justificada pelo intuito de se evitarem aumentos nas prevalências no grupo em estudo de alelos 
pertencentes àquela família e que na realidade não estariam associados ao PV, evitando-se assim associações falso-positivas. Do total inicial de 37 pacientes elegíveis para o estudo, havia consanguinidade entre dois indivíduos, o que nos surpreende já que, de acordo com observações de outros autores ${ }^{(16-20)}$, casos familiares de PV são raros. Embora os dados de apenas uma das irmãs tenham sido incluídos na análise, a tipagem foi realizada para ambas. Apresentavam HLA A e B idênticos: A23-A66 e B49-B53. Ambas carregavam também o alelo DRB1*04:02 associado ao PV, diferindo apenas no outro alelo de classe DR: a irmã incluída no estudo portava DRB1*11 e a outra DRB1*15.

Não há garantias de que o grupo controle não continha familiares de pacientes com PV. As informações relacionadas à saúde dos indivíduos incluídos no grupo controle (doadores voluntários de medula óssea) não questionava especificamente quanto à história pessoal ou familiar de pênfigos, e sim de maneira genérica quanto à presença de doenças crônicas pessoais ou familiares. Interpretamos, porém, que a possível presença deste fator no presente estudo - como um viés de seleção - não tenha invalidado os resultados positivos encontrados. A presença de indivíduos com genes "potencialmente" associados à doença no grupo controle, atenuaria as diferenças nas prevalências dos alelos entre os grupos, tornando mais difícil sua detecção. Este viés pode ter aumentado, portanto, a chance de resultados falsos-negativos, ou seja, deixar de encontrar uma associação entre algum alelo e a doença quando na verdade essa associação existe (erro tipo II). Este mesmo viés, no entanto, não poderia aumentar a chance de resultados falso- 
positivos e não invalida, portanto, a associação entre PV e HLA DRB1*04:02, DRB1*08:04 e DR14 encontrada.

Em geral, se uma doença é mais comum em um grupo étnico particular, indivíduos desse grupo (incluindo aqueles com ancestralidade parcial) são mais propensos a serem recrutados como casos do que como controles. Quaisquer variantes genéticas que forem mais frequentes nesse grupo, mesmo aquelas não relacionadas à doença, parecerão associadas ${ }^{(50)}$. Isto pode resultar em associações sem plausibilidade biológica que na verdade são secundárias a viés de seleção. Infelizmente, as frequências alélicas sabidamente variam intra e inter populações independentemente de estarem relacionadas às doenças. Essas disparidades nas frequências surgem porque cada população tem história genética e social únicas: padrões ancestrais de migração geográfica, tendências matrimoniais, períodos ou subgrupos com menor ou maior expansão de natalidade, além de variações aleatórias as quais resultam em diferenças nas frequências alélicas entre os indivíduos (intra e inter populações) mesmo que nenhuma esteja associada a qualquer doença específica.

Quando as amostras de casos e controles têm diferenças nas frequências alélicas em função de diferenças em suas origens étnicas não relacionadas à variável em estudo, diz-se que o estudo possui estratificação populacional ${ }^{(102)}$. Esta pode interferir nos resultados de estudos de associação de duas maneiras: primeiro, sutis desequilíbrios na ancestralidade entre casos e controles podem fazer com que diversos marcadores neutros pareçam estar associados à doença caso esses genes tenham frequências diferentes entre os 
grupos ancestrais (resultados falso-positivos). Segundo, uma heterogeneidade não observada em ambos casos e controles frequentemente atenua o sinal de associação caso ela esteja presente em apenas uma subpopulação ${ }^{\left({ }^{50)}\right.}$.

Apesar de haver grande potencial para conclusões espúrias secundárias à estratificação populacional não detectada em estudos de associação genética, de fato poucos são os estudos que encontraram resultados errôneos atribuíveis inequivocamente a estratificação alélica subjacente. A tentativa de controle desse viés por meio do pareamento de casos e controles durante a seleção dos indivíduos considerando todas as diferenças genéticas em uma população é impossível, e mesmo tentativas de pareamento utilizando características substitutivas, tais como proximidade geográfica, características físicas ou ancestralidade familiar auto-relatada, não garantem o controle de diferenças ancestrais populacionais ${ }^{(102)}$.

Em nosso estudo, apesar de haver significante diferença na composição de casos e controles quanto à cor da pele - maior prevalência de indivíduos de cor parda no grupo em estudo (tabela 3) - este fato não sugere diretamente que os grupos são heterogêneos do ponto de vista genético. Primeiramente, é preciso lembrar que a classificação de acordo com a cor da pele é subjetiva, realizada pelo entrevistador ou pelo próprio indivíduo entrevistado, não havendo critérios objetivos para essa classificação nem mesmo durante as avaliações censitárias periódicas realizadas pelo IBGE. Em seguida, como demonstrado por Pimenta e colaboradores ${ }^{(51)}$, não há na população brasileira correlação entre a cor da pele e a ancestralidade do indivíduo, graças à intensa 
miscigenação ao longo de diversas gerações. Uma vez que diferenças de ancestralidade entre casos e controles são as principais geradoras de estratificação populacional, mesmo se houvesse proporções de cor da pele equilibradas entre casos e controles no presente estudo, isso não garantiria a homogeneidade de variantes genéticas entre esses grupos.

Wacholder e colaboradores ${ }^{(104)}$ afirmam que o aumento do número de diferentes grupos étnicos na formação de uma população (e consequente aumento na miscigenação), de fato diminui o viés provocado pela estratificação populacional. Afirmam também que praticamente todas as populações não consanguíneas são confundidas por miscigenação, porém a grandeza de seu efeito tende a ser pequena, exceto em condições extremas. Essas condições extremas podem estar presentes em casos de populações com miscigenação recente e grandes variações interindividuais nas proporções de frequência genética secundárias a segregação social durante miscigenação e quando as incidências das doenças e as frequências alélicas têm diferenças significativas e associadas entre os grupos étnicos.

Todos os integrantes do grupo em estudo não apresentavam isolamento geográfico ou sócio-econômico e eram indivíduos cujos pais foram nascidos no Brasil. Além disso, todos, exceto uma paciente, tinham avós nascidos no Brasil. Essas características, associadas ao fato da população brasileira especialmente do estado de São Paulo - ser uma das mais heterogêneas e miscigenadas do mundo ${ }^{(82)}$, fazem com que a amostra estudada não seja considerada dentro das condições extremas propostas por Wacholder e 
colaboradores. Portanto, acreditamos que caso a estratificação populacional tenha ocorrido em nosso estudo, a probabilidade de ocorrência de resultados falso-positivos decorrentes de sua presença tenha sido muito pequena. Por outro lado, acreditamos que a intensa miscigenação ocorrida na população brasileira ao longo das centenas de anos de sua formação acaba por ser propícia à realização de estudos de associação, uma vez que genes anteriormente tidos como ligados a uma determinada doença decorrente de estratificação populacional tendem a ser diluídos e ocorrer menor chance de resultados falso-positivos .

\subsection{Associações entre alelos do sistema HLA e Pênfigo Vulgar}

O presente estudo demonstrou associação significante entre o PV e o complexo principal de histocompatibilidade, em particular os antígenos de classe II. Pacientes com Pênfigo Vulgar apresentaram prevalências dos alelos DRB1*04:02, DRB1*08:04 e DRB1*14 significativamente maior que o grupo controle. Evidências estatísticas para a associação entre um alelo e um fenótipo podem ser decorrentes de uma de três situações: primeiro, um alelo em si pode ser funcional e afetar diretamente a expressão do fenótipo; na segunda situação, o alelo pode estar relacionado ou estar em desequilíbrio de ligação 
com um alelo causador localizado nas proximidades. Na terceira situação, a associação pode ser um "falso positivo", atribuída ao acaso ou a vieses como os de confusão ou de seleção.

O alelo com maior força de associação encontrado em nosso estudo DRB1*04:02 - é encontrado em associação com o PV em amostras de doentes de populações de diversos locais no mundo, especialmente judeus Ashkenazi (40, 44, 45) e de regiões relacionadas ao mar mediterrâneo - espanhóis (29), franceses ${ }^{(30)}$, italianos ${ }^{(33,34)}$, sardenhos ${ }^{(47)}$ e turcos ${ }^{(48)}$. É também descrito em doentes iranianos ${ }^{(32)}$, norte-americanos ${ }^{(42-45)}$ e, na América do Sul, em argentinos ${ }^{(28)}$ e em venezuelanos ${ }^{(49)}$. Em nossa amostra, o alelo DRB1*04:02 esteve presente em 47,2 \% dos casos contra apenas 2,0 \% dos controles, o que conferiu aos portadores deste alelo risco relativo de apresentar PV 44,6 vezes o risco daqueles indivíduos que não o carregam (IC95\%: 19,2 - 103,5). Esta quantificação de risco está de acordo com aquela encontrada na maior parte dos estudos que apontaram associação deste alelo com PV, como apresentado na tabela 2. Dessa forma, os dados sugerem que aqueles indivíduos portadores deste alelo na população brasileira têm 44,6 vezes o risco de apresentarem PV quando comparados ao risco daqueles que não possuem este alelo. De maneira semelhante, o risco atribuível calculado estima que, dos pacientes brasileiros portadores de PV, 52,2\% são doentes por causa da presença deste fator.

O mecanismo pelo qual portadores do alelo DRB1*04:02 são mais suscetíveis ao PV foi estudado e é parcialmente compreendido. A molécula de 
HLA codificada por esse alelo contém um bolsão negativo no sítio de ligação aos peptídeos, o qual aumenta sua afinidade seletiva para a apresentação de alguns epítopos da molécula de Dsg3. As células apresentadoras de antígenos apresentam diferentes auto-antígenos da Dsg aos linfócitos T, levando a sua proliferação policlonal. Esse mecanismo foi reproduzido in vitro por diversos autores $(74,80,81,105,106)$. Nishifuji e colaboradores ${ }^{(73)}$ demonstram in vitro que a produção de IgG específica contra a Dsg pelos linfócitos B - que termina por provocar a agressão ao desmossomo e consequentemente o surgimento das manifestações clínicas - é dependente da estimulação dos linfócitos T específicos e da presença de moléculas HLA de classe II. Apesar de identificadas as células atuantes e a participação de cada uma na gênese da autoimunidade presente em doentes com PV portadores de HLA-DRB1*04:02, permanecem obscuras as razões pelas quais apenas alguns indivíduos portadores do gene desenvolvem a doença. Espera-se que algum fator ambiental - como a exposição a alguma substância ou patógeno - ainda não identificado seja o "gatilho" para que os linfócitos B específicos dos indivíduos suscetíveis percam a tolerância e passem a iniciar o mecanismo que leva à doença.

O bolsão negativo presente na molécula de HLA-DRB1*04:02 é secundário à presença de aminoácidos com carga negativa nas posições 70 e 74 no posição P4 desta molécula. Esta característica é exclusiva de apenas três dos 59 alelos DRB1*04 sequenciados até a presente data: 04:02, 04:14 e 04:37, porém apenas o 04:02 é associado ao pênfigo vulgar. Em nosso estudo 
a tipagem do indivíduo número 25 revelou DRB1*04BK (tabela 10). De acordo com o código NMDP ${ }^{(93)}$, este indivíduo pode ser portador das variantes 04:02 ou 04:14, o que será elucidado pela tipagem em alta resolução.

No presente estudo, o HLA-DRB1*14 foi carregado por $27,8 \%$ dos doentes e apenas 7,4 \% dos controles, estando associado ao PV com risco relativo de 4,8 (IC95\%: 2,2 - 10,4). Não foi possível, no entanto, em razão da metodologia utilizada na tipagem do HLA, especificar se alguma variante alélica específica foi a responsável pela maior prevalência no grupo em estudo; mais uma vez salientamos que isso será elucidado assim que realizada a tipagem em alta resolução. Diversos estudos apontaram a associação entre DR14 e PV em diferentes populações ao redor do mundo: sardenhos e italianos ${ }^{(34,47)}$, indianos ${ }^{(31)}$, paquistaneses ${ }^{(46)}$, espanhóis ${ }^{(29)}$, japoneses ${ }^{(35,38)}$, franceses ${ }^{(30)}$, mexicanos ${ }^{(41)}$, argentinos ${ }^{(28)}$ e venezuelanos ${ }^{(49)}$. Nenhum estudo, no entanto, identificou em nível celular ou molecular indícios que justificassem a participação direta deste alelo na gênese da autoimunidade em doentes com PV. A análise das moléculas de HLA das variantes alélicas do DRB1*14 revela que nenhum alelo apresenta bolsões negativos em seu sítio de ligação a peptídeos ${ }^{(45)}$. Diversos estudos ${ }^{(28-30,34,35,38,46,49)}$, porém, observam também que o DRB1*14 ocorre em frequente associação com DQB1*05:03, secundário a forte desequilíbrio de ligação entre esses alelos.

Lee e colaboradores ${ }^{(45)}$ relatam que a associação entre PV e DRB1*14 é significante naqueles pacientes que apresentam o haplótipo DRB1*14DQB1*05:03 e não ocorre em portadores de DRB1*14 isolado. Por outro lado, 
os mesmos autores observam que a presença isolada de DQB1*05:03 está associada ao PV, independente do alelo DR encontrado. A associação de diferentes DRB1*14 com DQB1*05:03 foi também foi relatada por Niizeki e colaboradores ${ }^{(39)}$, Delgado e colaboradores ${ }^{(46)}$ e Carcassi e colaboradores ${ }^{(47)}$. Mediante essas informações interpretamos que o aumento de risco encontrado na associação entre PV e DR14 observada em nosso estudo - assim como naqueles relatados na tabela 2 - se justificaria, na verdade, por desequilíbrio de ligação com o alelo DQB1*05:03. Acreditamos, portanto, que a maior prevalência de DRB1*14 na amostra de doentes estudados não decorre de resultado falso positivo, mas sim de associação indireta (decorrente de desequilíbrio de ligação) com um alelo de outro locus não estudado, este sim provavelmente envolvido na patogênese da doença, por algum mecanismo ainda não elucidado.

O alelo DRB1*08:04 esteve presente em 36,1\% dos pacientes com PV contra apenas 2,9\% dos controles (frequência alélica 0,017 vs 0,002). Indivíduos portadores do alelo DRB1*08:04 apresentaram 18,6 vezes o risco de ter PV quando comparados àqueles que não possuem este alelo. O risco atribuível calculado indica que, dos pacientes brasileiros portadores de PV, 35,0\% estiveram doentes em função de sua presença. Embora a associação entre PV e o alelo DRB1*08:04 já tenha sido observada em amostra de doentes italianos ${ }^{(47)}$, nenhum estudo havia encontrado prevalência de tamanha magnitude deste alelo em doentes com PV. Estudos que pesquisaram a frequência dos alelos HLA-DRB1 na população brasileira apontam frequências 
fenotípicas do DRB1*08:04 semelhantes às encontradas em nosso grupo controle: $1,9 \%$ em indivíduos caucasianos (frequência alélica $=0,010)^{(107)} \mathrm{e}$ $7,1 \%$ (frequência alélica $=0,036)$ em mulatos (pardos) ${ }^{(108)}$ em amostras da população provenientes do sudeste do Brasil, mesma região onde foi realizado nosso estudo. A tabela 13 apresenta as frequências alélicas e fenotípicas do alelo DRB1*08:04 em amostras de diferentes populações ao redor do mundo.

Tabela 13 - Frequências do alelo DRB1*08:04 em amostras de diferentes populações do mundo.

\begin{tabular}{lccccc}
\hline & & & \multicolumn{2}{c}{ Frequência } & \\
\cline { 4 - 5 } País & População & Origem Étnica & Fenotípica (\%) & Alélica & Amostra \\
\hline Brasil & Sudeste $^{(107)}$ & Caucasóides & 1,9 & 0,010 & $\mathrm{n}=103$ \\
& Sudeste $^{(109)}$ & Negros & & 0,043 & $\mathrm{n}=47$ \\
& Sudeste $^{(108)}$ & Pardos & 7,1 & 0,036 & $\mathrm{n}=42$ \\
& Nordeste $^{(110)}$ & Mista & & 0,025 & $\mathrm{n}=205$ \\
& Guarani $^{(111)}$ & Ameríndios & & 0,081 & $\mathrm{n}=93$ \\
Colômbia & Nordeste $^{(112)}$ & Negros & & 0,075 & $\mathrm{n}=20$ \\
& Sikuani $^{\left({ }^{(113)}\right.}$ & Ameríndios & & 0,037 & $\mathrm{n}=27$ \\
Sudão & Cartum $^{(114)}$ & Negros & 21,5 & 0,120 & $\mathrm{n}=200$ \\
Guiné Equatorial & Ilha Bioko $^{(115)}$ & Negros & & 0,075 & $\mathrm{n}=100$ \\
Itália & Roma $^{(116)}$ & Caucasóides & 5,0 & 0,025 & $\mathrm{n}=100$ \\
Suécia & Norte $^{(117)}$ & Caucasóides & & 0,016 & $\mathrm{n}=154$ \\
\hline
\end{tabular}


Observa-se que o alelo DRB1*08:04 é comum em populações africanas ao sul do deserto do Saara, ocorrendo com maior frequência como o haplótipo DRB1*08:04-DQB1*03:01 - $10 \%$ dos indivíduos da Guiné Equatorial, 7,7 \% da Etiópia, 5,1 \% do Congo e 4,0 \% do Camarões ${ }^{(114,115)}$. Já em amostras de populações européias e de comunidades indígenas da amazônia, é mais frequente na forma do haplótipo DRB $1 * 08: 04-\mathrm{DQB} 1 * 04: 02$, presente em 1,6\% dos italianos, 1,7\% dos caucasianos na Suécia e 8,1\% dos guaranis na amazônia ${ }^{(111,114,116)}$.

Uma vez que em nosso estudo a força de associação encontrada entre o alelo e PV foi de grande magnitude, e a frequência alélica nos controles foi semelhante às observadas por outros autores em amostras da mesma população ${ }^{(107-109)}$, acreditamos que a chance da associação entre PV e o alelo DRB1*08:04 ser um resultado falso positivo, secundário ao acaso ou à estratificação populacional, é muito pequena. Interpretamos que o alelo DRB1*08:04 deve estar realmente associado à doença na população brasileira; ou por estar envolvido diretamente na gênese da doença ou indiretamente por meio de algum gene localizado nas suas proximidades. É provável que os estudos realizados em outras populações não tenham sido capazes de demonstrar associação de tamanha magnitude entre este alelo e o PV pois em nenhum deles o recrutamento de pacientes envolveu indivíduos de populações cujas origens envolvessem a origem africana. Conforme apresentado na tabela 12, o alelo DRB1*08:04 esteve presente nos dois indivíduos (100\%) 
classificados como de cor negra e em 7 (50\%) de cor parda do grupo com PV, reforçando esta teoria.

Arnett e colaboradores ${ }^{(118)}$ observam associação entre o haplótipo DRB1*08:04-DQB1*03:01 e esclerodermia em indivíduos afro-americanos, e Li e colaboradores ${ }^{(119)}$ observam que portadores deste mesmo haplótipo apresentam maiores chances de produção de altos níveis de anticorpos em resposta à vacina contra o vírus da Hepatite $\mathrm{B}$, independente de outros fatores como status de infecção pelo HIV, idade ou origem étnica.

A realização de múltiplas comparações no presente estudo entre as prevalências de alelos em casos e controles aumenta a chance de que associações "falso-positivas" sejam encontradas simplesmente pelo acaso. O pressuposto de que as associações estatisticamente significantes são aquelas nas quais o valor de $\mathrm{P}$ é menor que 0,05 indica que a chance de tal associação ser ao acaso é inferior a 5/100 (ou 5\%). À medida que múltiplas comparações vão sendo realizadas entre os grupos, no entanto, aumentam as chances de se encontrar uma associação falsamente positiva (erro tipo I). Quando realizadas 24 comparações, por exemplo, estima-se a chance de $70,8 \%$ de que pelo menos uma associação encontrada seja justificada pelo acaso ${ }^{(120)}$. Austin e colaboradores ${ }^{(120)}$ demonstram que associações espúrias, sem plausibilidade biológica, como a associação entre signos do zodíaco e internação por doenças podem ser encontradas decorrentes simplesmente do acaso, quando se realizam múltiplas comparações em amostras suficientemente grandes. Portanto, é consenso entre diversos autores ${ }^{(50,95-97,120)}$ que para minimizar o 
risco de erro tipo I em estudos exploratórios - os quais envolvem múltiplas comparações entre grupos - é necessário o ajuste do valor do $\mathrm{P}$ a ser considerado estatisticamente significante. Dentre as diferentes estratégias que visam esse objetivo, escolhemos a utilização do método FDR, por ser considerado o mais adequado em estudos exploratórios em genética ${ }^{(50)}$.

Os estudos que encontraram diferentes alelos do locus DRB1 em associação com o PV, citados na tabela 2, também realizaram controle de comparações múltiplas, embora tenham utilizado diferentes métodos, o que nos impede de inferir que o grande número de alelos encontrados nos resultados desses estudos sejam associações falso-positivas, secundárias a metodologia inadequada.

Em nosso estudo, o valor de $\mathrm{P}$ corrigido pelo método FDR considerado estatisticamente significante foi de 0,00113173. A partir do teste exato de Fisher obtivemos valores de $\mathrm{P}$ abaixo do valor crítico para os alelos DR4 (DRB1*04:02), DR8 (DRB1*08:04) e DR14. Outros cinco alelos seriam considerados estatisticamente significantes caso não fosse realizada correção para múltiplos testes: B15 ( $p=0,019), \mathrm{DRB}^{*} 15(p=0,012)$, B53 $(p=0,004)$, DRB1*13 $(p=0,003)$ e B57 $(p=0,002)$. Três destes - B15, DRB1*13 e DRB1*15 - foram menos freqüentes no grupo de pacientes e portanto não estavam associados ao PV. Embora DRB1*13 já tenha sido negativamente correlacionado com o PV ${ }^{(47)}$, nenhum estudo até o momento demonstrou efeito preventivo direto em indivíduos que carreguem qualquer alelo identificado como negativamente associado ao PV ${ }^{(45)}$. Embora não tenha sido 
demonstrado desequilíbrio de ligação entre B53 e DRB1*08 ( $\left.\mathrm{D}^{\prime}=0,06944\right)$, acreditamos que a tendência em haver associação entre os alelos B53 e PV na verdade se deveu pela grande prevalência do haplótipo B53-DRB1*08; 26,7\% dos indivíduos portadores de B53 também apresentavam DRB1*08, e dos que apresentavam DRB1*08, 12,1\% também apresentavam B53 $(p=0,011)$.

Por fim, nosso estudo objetivou colaborar com a descoberta de diferentes alelos associados ao PV, o que pode direcionar a pesquisa na elucidação de diferentes mecanismos fisiopatológicos que levam à gênese da autoimunidade no pênfigo vulgar. O melhor entendimento dos mecanismos envolvidos na doença podem, por sua vez, possibilitar o desenvolvimento de estratégias para prevenção e para o desenvolvimento de formas alternativas de tratamento mais eficazes e específicas que as atualmente disponíveis. 


\section{CONCLUSÕES}

A tipificação do HLA da amostra de portadores do Pênfigo Vulgar e controles provenientes da população Brasileira indicou que os alelos HLA DRB1*04:02, DRB1*08:04 e DRB1*14 estão associados à doença, com riscos relativos de 44,6 (19,2 a 103,5), 18,6 (8,3 a 41,7) e 4,8 (2,2 a 10,4), respectivamente.

A associação entre Pênfigo Vulgar e DRB1*04:02 é bem estabelecida na literatura e possui mecanismos fisiopatológicos para a gênese de autoimunidade propostos porém parcialmente compreendidos.

É necessária a realização da tipagem de outros loci dos pacientes estudados, especialmente DQB1 e DQA1 para diferenciar se a associação encontrada entre PV e os alelos DRB1*08:04 e DRB1*14 deve-se a desequilíbrio de ligação entre outros alelos HLA de classe II localizados nas proximidades ou se realmente apresenta associação independente de outros fatores, indicando participação direta na gênese da autoimunidade de Pênfigo Vulgar. 


\section{ANEXOS}

Anexo A - Equilíbrio de Hardy-Weinberg e Desequilíbrio de Ligação ${ }^{(78)}$

\section{Equilíbrio de Hardy-Weinberg}

Da mesma maneira que a maioria das variáveis contínuas na medicina cumprem distribuição normal, a maioria das distribuições dos alelos seguem o chamado equilíbrio de Hardy-Weinberg (EHW). A lei de Hardy-Weinberg determina que, se existem dois alelos para um determinado locus, chamados $A$ e a, com frequências $p$ e $q$, respectivamente, após uma geração de cruzamentos aleatórios, as frequências dos grupos de genótipos $A A$, Aa e aa na população serão $p^{2}, 2 p q$ e $q^{2}$, respectivamente. Dado que existem apenas dois alelos possíveis, $A$ ou a, então $p+q=1$ e $p^{2}+2 p q+q 2=1$, conforme apresentado na figura 11 .

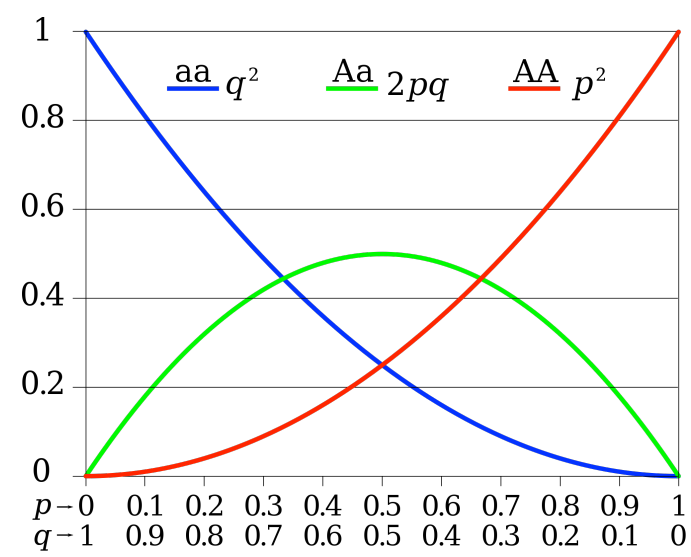

Figura 11: Princípio de Hardy-Weinberg para dois alelos. O eixo horizontal mostra as duas frequências alélicas $p$ e $q$, o eixo vertical mostra as frequências genotípicas e os três possíveis genótipos são representados pelos diferentes glifos. (Fonte: http://en.wikipedia.org/wiki/File:Hardy-Weinberg.svg) 
É prática corriqueira em estudos de associação genética verificar o quanto que as frequências alélicas observam as proporções do EHW. Desvios do EHW na população podem ser resultantes dos seguintes fatores:

- Consanguinidade, ou seja, casamentos entre parentes próximos, pois o EHW depende de intercruzamentos aleatórios

- Deriva Gênica, processo na qual a população é isolada, com um número limitado de possibilidades de intercruzamentos

- Migração

- Novas mutações: apenas mutações muito recentes podem quebrar o EHW pois o equilíbrio é geralmente alcançado dentro de uma geração em uma população grande o suficiente.

- Seleção, ou seja, uma desvantagem seletiva de um alelo em particular leva à morte fetal.

Desvios do EHW também podem ser sinal de problemas metodológicos em estudos genéticos (erros na genotipagem ou estratificação populacional).

\section{Desequilíbrio de Ligação}

Em estudos de associação genética, um dos objetivos é estabelecer quando um polimorfismo específico é causador de determinado desfecho, como presença ou ausência de determinada doença. Isso requer o isolamento da função de um polimorfismo de outro que pode estar próximo no gene, o que pode ser difícil pois fragmentos do genoma tendem a ser herdados em 
conjunto, como uma unidade (situação conhecida como Desequilíbrio de Ligação). Assim, a associação de um polimorfismo com um desfecho, não importando o quão forte seja a força dessa associação, pode não ser de causalidade. É possível que este polimorfismo esteja em desequilíbrio de ligação (DL) com outro que realmente seja causador da doença.

Como exemplo, consideremos o polimorfismo $A$ com uma frequência alélica comum de $80 \%$ e o polimorfismo B com uma frequência alélica de $60 \%$. Se não houver conexão entre o os polimorfismos para que possam ser herdados em bloco, eles serão encontrados ao mesmo tempo em um determinado indivíduo em cerca de $0,80 \times 0,6=36 \%$ das vezes, ou seja, compatível com a probabilidade. No entanto, se houver DL perfeito, quando por exemplo os polimorfismos estão muito próximos e sempre são herdados em conjunto, pode ser que o alelo $A$ sempre seja encontrado em associação ao alelo $B$. O grau de desequilíbrio de ligação pode ser expresso numericamente por $D^{\prime}$, de maneira que o valor 1 indica que os dois alelos são sempre encontrados juntos. 
Anexo B - Termo de Aprovação do Comitê de Ética para Análise de Projetos de Pesquisa

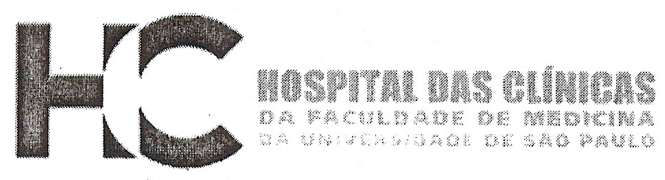

\section{APROVAÇÃO}

A Comissão de Ética para Análise de Projetos de Pesquisa - CAPPesq da Diretoria Clínica do Hospital das Clínicás e da Faculdade de Medicina da Universidade de São Paulo, em sessão de 08.11.06, APROVOU o Protocolo de Pesquisa $n^{\circ}$ 1045/06, intitulado: "Estudo da correlação entre antígenos de histocompatibilidade (HLA), pênfigo vulgar e suas manifestações clínico histopatológicas em brasileiros" apresentado pelo Departamento de Oftalmologia e Otorrinolaringologia, inclusive o Termo de Consentimento Livre e Esclarecido.

Cabe ao pesquisador elaborar e apresentar à CAPPesq, os relatórios parciais e final sobre a pesquisa (Resolução do Conselho Nacional de Saúde n 196, de 10.10.1996, inciso IX. 2, letra "c")

Pesquisador(a) Responsável: DR. Ivan Dieb Miziara

Pesquisador (a) Executante: DR. Raimar Weber

CAPPesq, 08 de novembro de 2006.

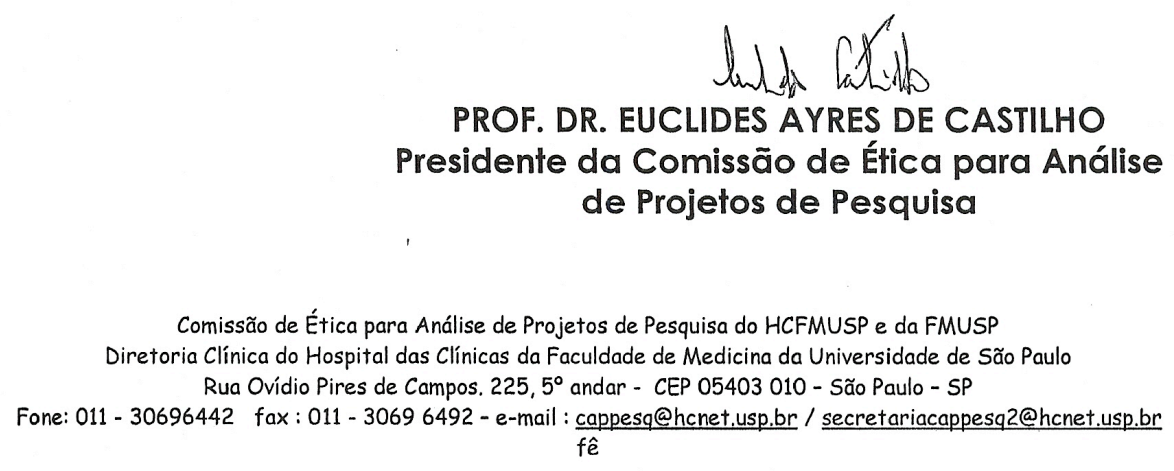


Anexo C - Termo de consentimento livre e esclarecido

HOSPITAL DAS CLÍNICAS

DA

FACULDADE DE MEDICINA DA UNIVERSIDADE DE SÃO PAULO

TERMO DE CONSENTIMENTO LIVRE E ESCLARECIDO

\section{I - DADOS DE IDENTIFICAÇÃO DO SUJEITO DA PESQUISA OU RESPONSÁVEL LEGAL}

1. NOME DO PACIENTE

DOCUMENTO IDENTIDADE No : SEXO:.$M \quad F$

DATA NASCIMENTO: ......................

ENDEREÇO

$\mathrm{N}^{\mathrm{O}}$ APTO:

BAIRRO:

CIDADE

CEP:

TELEFONE: DDD (...)........

2.RESPONSÁVEL LEGAL

NATUREZA (grau de parentesco, tutor, curador etc.)

DOCUMENTO DE IDENTIDADE : SEXO: $M$

F DATA NASCIMENTO.: ....................

ENDEREÇO: $\mathrm{N}^{\circ}$ APTO BAIRRO: CIDADE:

CEP: TELEFONE: DDD (. ..). 


\section{II - DADOS SOBRE A PESQUISA CIENTÍFICA}

1. TÍTULO DO PROTOCOLO DE PESQUISA. Estudo da correlação entre antígenos de histocompatibilidade (HLA), Pênfigo Vulgar e suas manifestações Clínico-Histopatológicas

PESQUISADOR: Ivan Dieb Miziara

CARGO/FUNÇÃO: Médico Chefe Ambulatório de Otorrinolaringologia

INSCRIÇÃO CONSELHO REGIONAL Nº 45484

UNIDADE DO HCFMUSP: Divisão de Clínica de Otorrinolaringologia

3. AVALIAÇÃO DO RISCO DA PESQUISA:

$\begin{array}{lll}\text { SEM RISCO } & X & \text { RISCO MíNIMO } \\ \text { RISCO BAIXO } & \text { RISCO MAIOR } & \text { RISCO MÉDIO }\end{array}$

(probabilidade de que o indivíduo sofra algum dano como consequência imediata ou tardia do estudo)

4.DURAÇÃO DA PESQUISA : 18 meses

\section{III - REGISTRO DAS EXPLICAÇÕES DO PESQUISADOR AO PACIENTE OU SEU REPRESENTANTE LEGAL SOBRE A PESQUISA CONSIGNANDO:}

1. justificativa e os objetivos da pesquisa.

Para ter certeza que você não tem outras doenças terá que realizar exame de sangue, para isso haverá a necessidade de tirar uma pouco do seu sangue.

2. procedimentos que serão utilizados e propósitos, incluindo a identificação dos procedimentos que são experimentais.

Será feita a retirada de uma pequena quantidade de sangue. Com este sangue serão feitos os exames para saber o que causou as feridas.

3. desconfortos e riscos esperados.

Haverá o pequeno desconforto da picada da agulha necessária para retirada do sangue, sem que haja risco algum.

4. benefícios que poderão ser obtidos.

Como benefício você irá ajudar a identificar a possível causa das feridas.

5. procedimentos alternativos que possam ser vantajosos para o indivíduo.

Nenhum. 


\section{IV - ESCLARECIMENTOS DADOS PELO PESQUISADOR SOBRE GARANTIAS DO SUJEITO DA PESQUISA CONSIGNANDO:}

1. acesso, a qualquer tempo, às informações sobre procedimentos, riscos e benefícios relacionados à pesquisa, inclusive para dirimir eventuais dúvidas.

Durante todo tratamento você terá acesso, a qualquer tempo, para observar a ficha onde ficarão guardadas todas as suas informações, e terá liberdade para fazer perguntas para esclarecer qualquer dúvida.

2. liberdade de retirar seu consentimento a qualquer momento e de deixar de participar do estudo, sem que isto traga prejuízo à continuidade da assistência.

O tratamento não depende da sua participação neste estudo. Você tem a liberdade de deixar de participar do estudo a qualquer momento e retirar o seu consentimento, sem que isso prejudique ou altere seu tratamento.

3. salvaguarda da confidencialidade, sigilo e privacidade.

Em nenhum momento durante o tratamento e na publicação dos resultados deste estudo você terá seu nome exposto, estando assim sua participação neste estudo em segredo.

4. disponibilidade de assistência no HCFMUSP, por eventuais danos à saúde, decorrentes da pesquisa.

Você terá assistência no Hospital das Clínicas da Faculdade de Medicina da USP por qualquer dano que por acaso venha ocorrer à sua saúde decorrente deste estudo.

5. viabilidade de indenização por eventuais danos à saúde decorrentes da pesquisa.

Nenhum

\section{INFORMAÇÕES DE NOMES, ENDEREÇOS E TELEFONES DOS RESPONSÁVEIS PELO ACOMPANHAMENTO DA PESQUISA, PARA CONTATO EM CASO DE INTERCORRÊNCIAS CLÍNICAS E REAÇÕES ADVERSAS.}

Raimar Weber - Rua Borges Lagoa, 1.450 Tel. 5080.4357 


\section{OBSERVAÇÕES COMPLEMENTARES:}

\section{VII - CONSENTIMENTO PÓS-ESCLARECIDO}

Declaro que, após convenientemente esclarecido pelo pesquisador e ter entendido o que me foi explicado, consinto em participar do presente Protocolo de Pesquisa

São Paulo, de de 20 
Anexo D - Protocolo de avaliação de sinais e sintomas clínicos

\begin{tabular}{|c|c|c|c|}
\hline \multicolumn{4}{|l|}{ DADOS DEMOGRÁFICOS } \\
\hline Paciente Númcro: & & Rcgistro HC: & \\
\hline Data de nascimento: $/ /$ & Data da avaliação: $/ /$ & Sexo: $\square$ 1. Masculino & $\square$ 2. Feminino \\
\hline
\end{tabular}

\begin{tabular}{|c|c|c|}
\hline \multicolumn{3}{|l|}{$\begin{array}{l}\text { SINTOMATOLOGIA ORL } \\
\end{array}$} \\
\hline \multicolumn{3}{|l|}{ Início dos sintomas: } \\
\hline Obstrução nasal & 口0. Nấo & $\square$ 1. Sim \\
\hline Crostas nasais & 口0. Não & ㄷ 1. Sim \\
\hline Epistaxe & 口0. Não & $\square$ 1.Sim \\
\hline Rinorréia com raias de sangue & $\square 0$. Não & $\square$ 1. Sim \\
\hline Disfagia: & $\square 0$. Não & $\square$ 1. Sim \\
\hline Odinofagia: & 口0. Não & $\square$ 1.Sim \\
\hline Sensação de CE / Globus faríngeo: & $\square 0$. Não & ㅁ 1.Sim \\
\hline Disfonia: & $\square 0$. Não & ㅁ.Sim \\
\hline Em remissão? & ㅁ. Não & ㅁ 1.Sim \\
\hline
\end{tabular}

\begin{tabular}{|c|c|}
\hline \multicolumn{2}{|c|}{ ENVOLVIMENTO DO PÊNFIGO } \\
\hline Pele: & $\square$ 0.Sem história de lesões $\square$ 1. Com lesões ativas ou passadas \\
\hline Conjuntiva & ㅁ.Sem história de lesões $\square$ 1. Com lesões ativas ou passadas \\
\hline Genitais & $\square$ 0.Sem história de lesões $\square$ 1. Com lesões ativas ou passadas \\
\hline
\end{tabular}

\section{ACHADOS À OROSCOPIA}

ㅁ.Sem história de lesões $\square$ 1. Com lesões ativas ou passadas

ACHADOS A NASOFIBROLARINGOSCOPIA

Cavidade nasal e rinofaringe: $\square$ 0.Sem história de lesões $\square$ 1. Com lesões ativas ou passadas

Hipofaringe: $\quad \square$ 0.Sem história de lesôes $\square$ 1. Com lesôes ativas ou passadas

Laringe: $\square 0$. Sem história de lesões $\square$ 1. Com lesões ativas ou passadas

Exame não realizado

\begin{tabular}{llll|}
\hline EXAMES & & & \\
\hline Imunofluorescência direta para C3 & $\square 0$. Ausente & $\square$ 1. Presente & $\square$ 9. Não realizada \\
\hline Imunofluorescência direta para IgG & $\square 0$. Ausente & $\square$ 1. Presente & $\square$ 9. Nầo realizada \\
\hline Imunofluorescência indireta & $\square 0$. Ausente & $\square$ 1. Presente título 1/ \\
\hline Antidesmogleína 1 & $\square 0$. Ausente & $\square$ 1. Presente & $\square$ 9. Não realizadizada \\
\hline Antidesmogleína 3 & $\square 0$. Ausente & $\square$ 1. Presente & $\square$ 9. Não realizada \\
\hline
\end{tabular}

Data Coleta de Sangue:

\begin{tabular}{l|}
\hline TIPIFICAÇ̃̃O DO HLA \\
\hline HLA A: \\
\hline HLA B: \\
\hline HLA DR: \\
\hline
\end{tabular}


Anexo E - Resultados dos testes de Equilíbrio de Hardy-Weinberg para as populações estudadas computados pelo programa Arlequin 3.0

(Locus $1=\mathrm{A}, 2=\mathrm{B}$ e $3=\mathrm{DR}$ )

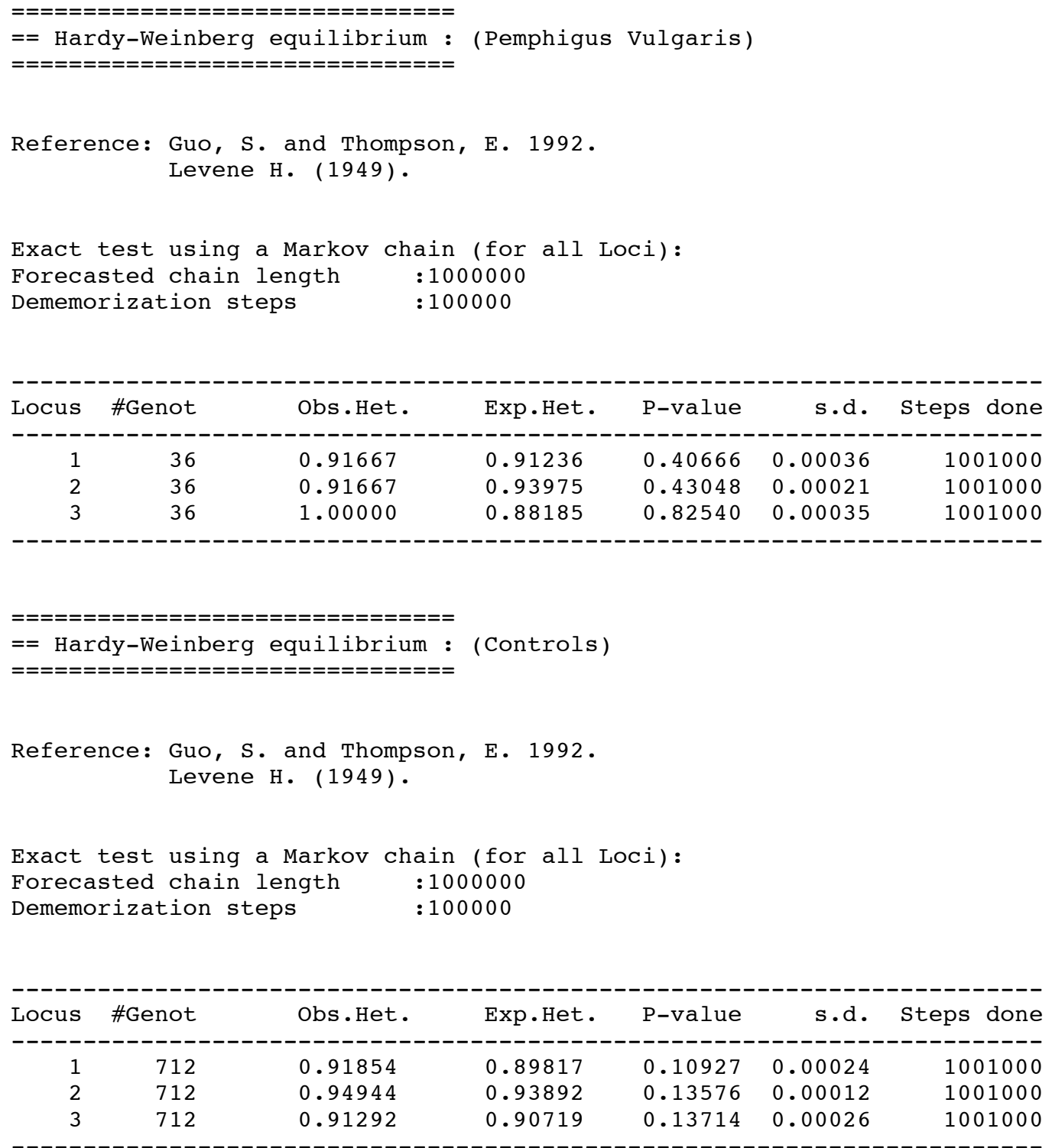




\section{REFERÊNCIAS}

1. Black M, Mignogna MD, Scully C. Pemphigus Vulgaris. Oral Dis. 2005;11:119-30.

2. Weinberg MA, Insler MS, Campen RB. Mucocutaneous features of autoimmune blistering diseases. Oral Surg Oral Med Oral Pathol Oral Radiol Endod. 1997;84:517-34.

3. Scully C, Almeida OPD, Porter SR, Gilkes JJ. Pemphigus vulgaris: the manifestations and long-term management of 55 patients with oral lesions. Br J Dermatol. 1999;140:84-9.

4. Ahmed AR, Moy R. Death in pemphigus. J Am Acad Dermatol. $1982 ; 7: 221-8$.

5. Robinson J, Lozada-Nur F, Frieden I. Oral pemphigus vulgaris: a review of the literature and a report on the management of 12 cases. Oral Surg Oral Med Oral Pathol Oral Radiol Endod. 1997;84:349-55.

6. Gazit E, Loewenthal R. The immunogenetics of pemphigus vulgaris. Autoimmun Rev. 2005;4:16-20.

7. Tsankov N, Vassileva S, Kamarashev J, Kazandjieva J, Kuzeva V. Epidemiology of pemphigus in Sofia, Bulgaria. A 16-year retrospective study (1980-1995). Int J Dermatol. 2000;39:104-8.

8. Tallab T, Joharji H, Bahamdan K, Karkashan E, Mourad M, Ibrahim K. The incidence of pemphigus in the southern region of Saudi Arabia. Int J Dermatol. 2001;40:570-2.

9. Hahn-Ristic K, Rzany B, Amagai M, Brocker EB, Zillikens D. Increased incidence of pemphigus vulgaris in southern Europeans living in Germany compared with native Germans. J Eur Acad Dermatol Venereol. 2002;16:68-71. 
10. Pisanti S, Sharav Y, Kaufman E, Posner LN. Pemphigus Vulgaris: incidence in Jews of different ethnic groups according to age, sex and initial lesion. Oral Surg. 1974;38(382-387).

11. Scully C, Challacombe SJ. Pemphigus Vulgaris: Update on Etiopathogenesis, Oral Manifestations and Management. Crit Rev Oral Biol Med. 2002;13(5):397-408.

12. Nishikawa T, Hashimoto $T$, Shimizu $H$, Ebihara T, Amagai $M$. Pemphigus: from immunofluorescence to molecular biology. J Dermatol Sci. 1996;12:1-9.

13. Kalish RS. Pemphigus vulgaris: the other half of the story. J Clin Invest. 2000;106:1433-5.

14. Anhalt GJ, Diaz LA. Prospects for autoimmune disease: research advances in pemphigus. JAMA. 2001;285:652-4.

15. Kowalewski C, Mackiewicz W, Schmitt D, Jablonska S, Haftek M. Cellcell junctions in acantholytic diseases. Junction proteins in nonimmune and autoimmune acantholysis. Arch Dermatol Res. 2001;293:1-11.

16. Laskaris G, Sklavounou A, Stavrou A, Stavropoulou K. Familial pemphigus vulgaris with oral manifestations affecting two Greek families. J Oral Pathol Med. 1989;18:49-53.

17. Katzenelson V, David M, Zamir R, Mellibovsky J, Idises C, Sandbank M. Familial pemphigus vulgaris. Dermatologica. 1990;181:48-50.

18. Feinstein A, Yorav S, Movshovitz M, Schewach-Millet M. Pemphigus in families. Int J Dermatol. 1991;30:347-51.

19. Stavropoulos PG, Zarafonitis G, Petridis A, Hashimoto T, Harman KE, Black MM. Pemphigus vulgaris in two sisters. Acta Derm Venereol. $2001 ; 81: 149$.

20. Starzycki Z, Chorzelski TP, Jablonska S. Familial pemphigus vulgaris in mother and daughter. Int J Dermatol. 1998;37:211-4.

21. Tron F, Gilbert D, Mouquet H, Joly P, Drouot L, Makni S, et al. Genetic factors in pemphigus. J Autoimmun. 2005;24:319-28. 
22. Firooz A, Mazhar A, Ahmed AR. Prevalence of autoimmune diseases in family members of patients with pemphigus vulgaris. J Am Acad Dermatol. 1994;33:319-20.

23. Pitoia F, Moncet D, Glorio R, Diaz AG, Costa GR, Carbia S, et al. Prevalence of thyroid autoimmunity in patients with Pemphigus Vulgaris. Medicina (B Aires). 2005;65(4):307-10.

24. Ahmed AR, Mohimen A, Yunis EJ, Mlrza NM, Kumar V, Beutner EH, et al. Linkage of pemphigus vulgaris antibody to the major histocompatibility complex in healthy relatives of patients. J Exp Med. 1993;177(419-424).

25. Brandsen R, Frusic-Zlotkin M, Lyubimov H, Yunes F, Michel B, Tamir A, et al. Circulating pemphigus IgG in families of patients with pemphigus: comparison of indirect immunofluorescence, direct immunofluorescence, and immunoblotting. J Am Acad Dermatol. 1997;36(1):44-52.

26. Mohimen A, Narula M, Ruocco V. Presence of the autoantibody in healthy relatives of Italian patients with pemphigus vulgaris. Arch Dermatol Res. 1993;285:176-7.

27. Klein J, Sato A. Advances in Immunology: The HLA System (First of Two Parts). NEJM. 2000;343(10):702-9.

28. Glorio R, Costa GR, Haas R, Gruber M, Fainboim L, Woscoff A. HLA Haplotypes and Class II Molecular Alleles in Argentinian Patients with Pemphigus Vulgaris. J Cutan Med Surg. 2002;6(5):422-6.

29. Gonzalez-Escribano MF, Jimenez G, Walter K, Montes M, Perez-Bernal AM, Rodriguez MR, et al. Distribution of HLA class II alleles among Spanish patients with pemphigus vulgaris. Tissue Antigens. 1998;52:275-8.

30. Loiseau P, Lecleach L, Prost C, Lepage V, Busson M, Bastuji-Garin S, et al. HLA Class II Polymorphism Contributes to Specify Desmoglein Derived Peptides in Pemphigus Vulgaris and Pemphigus Foliaceus. J Autoimmun. 2000;15:67-73. 
31. Delgado JC, Yunis DE, Bozon MV, Salazar M, Deulofeut R, Turbay D, et al. MHC class II alleles and haplotype in patients with pemphigus vulgaris from India. Tissue Antigens. 1996;48:668-72.

32. Mobini N, Yunis EJ, Alper CA, Yunis JJ, Delgado JC, Yunis DE, et al. Identical MHC markers in non-Jewish Iranian and Ashkenazi Jewish patients with pemphigus vulgaris: possible common central Asian ancestral origin. Hum Immunol. 1997;57(1):62-7.

33. Lombardi ML, Mercuro O, Tecame G, Fusco C, Ruocco V, Salerno A, et al. Molecular analysis of HLA DRB1 and DQB1 in Italian patients with pemphigus vulgaris. Tissue Antigens. 1996;47:228-30.

34. Lombardi ML, Mercuro O, Ruocco V, Schiavo AL, V VL, Guerrera V, et al. Common human leukocyte antigen alleles in pemphigus vulgaris and pemphigus foliaceus in Italian patients. J Invest Dermatol. 1999;113(1):107-10.

35. Miyagawa S, Higashimine I, lida T, Yamashina Y, Fukumoto T, Shirai T. HLA-DRb1*04 and DRb1*14 alleles are associated with susceptibility to pemphigus among Japanese. J Invest Dermatol. 1997;109:615-8.

36. Miyagawa $S$, Amagai $M$, Niizeki $H$, Yamashina $Y$, Kaneshige $T$, Nishikawa T, et al. HLA-DRB1 polymorphisms and autoimmune responses to desmogleins in Japanese patients with pemphigus. Tissue Antigens. 1999;54(4pt1):333-40.

37. Miyagawa S, Niizeki H, Yamashina Y, Kaneshige T. Genotyping for HLA-A, B and C alleles in Japanese patients with pemphigus: prevalence of Asian alleles of the HLA-B15 family. Br J Dermatol. 2002;146:52-8.

38. Yamashina Y, Miyagawa S, Kawatsu T, lida T, Higashimine I, Shirai T, et al. Polymorphisms of HLA class II genes in Japanese patients with pemphigus vulgaris. Tissue Antigens. 1998;52(1):74-7.

39. Niizeki H, Inoko H, Mizuki N, Inamoto N, Watababe K, Hashimoto T, et al. HLA-DQA1, -DQB1 and -DRB1 genotyping in Japanese pemphigus vulgaris patients by the PCR-RFLP method. Tissue Antigens. 1994;44(4):248-51. 
40. Ahmed AR, Yunis EJ, Khatri K, Wagner R, Notani G, Z ZA. Major histocompatibility complex haplotype studies in Ashkenazi Jewish patients with pemphigus vulgaris. Proc Natl Acad Sci USA. 1990;1990:7658-62.

41. Vega-Memije ME, Ocariz-Gutiérrez MdMSd, Cortés-Franco R, Domínguez-Soto L, Granados-Arriola J. Análisis de HLA-DR en pacientes mexicanos con pénfigo. Gac Med Mex. 2001;137(6):535-40.

42. Scharf SJ, Friedmann A, Brautbar C, Szafer F, Steinman L, Horn G, et al. HLA class II allelic variation and susceptibility to pemphigus vulgaris. Proc Natl Acad Sci U S A. 1988;85(10):3504-8.

43. Scharf SJ, Friedmann A, Steinman L, Brautbar C, Erlich HA. Specific HLA-DQB and HLA-DRB1 alleles confer susceptibility to pemphigus vulgaris. Proc Natl Acad Sci U S A. 1989;86(16).

44. Ahmed AR, Wagner R, Khatri K, Notani G, Awdeh Z, Alper CA, et al. Major histocompatibility complex haplotypes and class II genes in nonJewish patients with pemphigus vulgaris. Proc Natl Acad Sci U S A. 1991;88(11):5056-60.

45. Lee E, Lendas KA, Chow S, Pirani Y, Gordon D, Dionisio R, et al. Disease Relevant HLA Class II Alleles Isolated by Genotypic, Haplotypic, and Sequence Analysis in North American Caucasians With Pemphigus Vulgaris. Hum Immunol. 2006;67:125-39.

46. Delgado JC, Hameed A, Yunis JJ, Bhol K, Rojas AI, Rehman SB, et al. Pemphigus Vulgaris Autoantibody Response is Linked to HLADQB1*0503 in Pakistani Patients. Hum Immunol. 1997;57:110-9.

47. Carcassi C, Cottoni F, Floris L, Vacca A, Mulargia M, Arras M, et al. HLA haplotypes and class II molecular alleles in Sardinian and Italian patients with pemphigus vulgaris. Tissue Antigens. 1996;48:662-7.

48. Birol A, Anadolu RY, Tutkak H, Gürgey E. HLA-class 1 and class 2 antigens in Turkish patients with pemphigus. Int Soc Dermatol. 2002;41:79-83. 
49. Sáenz-Cantele AM, Fernández-Mestre M, Montagnani S, Calebotta A, Balbas O, Layrisse Z. HLA-DRB1*0402 haplotypes without DQB1*0302 in Venezuelan patients with pemphigus vulgaris. Tissue Antigens. 2007;69:318-25.

50. Li J. Genetic Association Studies: Concepts and Applications. In: Deng H-W, Shen H, Liu Y-J, Hu H, editors. Current Topics in Human Genetics - Studies in Complex Diseases. 1a ed. Singapore: World Scientific Publishing Co. Pte. Ltd.; 2007. p. 65-94.

51. Pimenta JR, Zuccherato LW, Debes AA, Maselli L, Soares RP, MouraNeto RS, et al. Color and genomic ancestry in Brazilians: a study with forensic microsatellites. Hum Hered. 2006;62(4):190-5.

52. Scully C, Bagan J-V, Black M, Carrozzo M, Eisen D, Escudier M, et al. Epithelial biology. Oral Dis. 2005;11:58-71.

53. Green KJ, Gaudry CA. Are desmosomes more than tethers for intermediate filaments? Nat Rev Mol Cell Biol. 2000;1:208-16.

54. Hertl M, Eming Rd, Veldman C. T cell control in autoimmune bullous skin disorders. J Clin Invest. 2006;116:1159-66.

55. Hietanen J, Salo OP. An epidemiological study of patients treated in Finnish hospitals between 1969 e 1978. Acta Derm Venereol (Stockh). $1982 ; 62: 491-6$.

56. Micali G, Musumeci ML, Nasca MR. Epidemiologic analysys and clinical course of 84 consecutive cases of pemphigus in eastern Sicily. Int J Dermatol. 1998;37:197-200.

57. Uzun S, Durdu M, Akman A, Gunasti S, Uslular C, Memisoglu HR, et al. Pemphigus in the Mediterranean region of Turkey: A study of 148 cases. Int J Dermatol. 2006;45:523-8.

58. V'Ickova-Laskoska MT, Laskoski DS, Kamberova S, Caca-Biljanovska N, Volckova N. Epidemiology of pemphigus in Macedonia: A 15-year retrospective study (1990-2004). Int J Dermatol. 2007;46:253-8. 
59. Langan SM, Smeeth L, Hubbard R, Fleming KM, Smith CJP, West J. Bullous pemphigoid and pemphigus vulgaris - incidence and mortality in the UK: population based cohort study. BMJ. 2008;337(91):a180.

60. Michailidou EZ, Belazi MA, Markopoulos AK, Tsatsos MI, Mourellou ON, Antoniades DZ. Epidemiologic survey of pemphigus vulgaris with oral manifestations in northern Greece: Retrospective study of 129 patients. Int J Dermatol. 2007;46:356-61.

61. Korman N. Pemphigus. J Am Acad Dermatol. 1988;18:1219-38.

62. Ariyawardana A, Tilakaratne WM, Dissanayake M, Vitanaarachchi N, Basnayake LK, Sitheeque MAM, et al. Oral pemphigus vulgaris in children and adolescents: a review of the literature and a case report. Int J Paediatr Dent. 2005;15:287-93.

63. Miziara ID, Filho JAX, Ribeiro FC, Brandão AL. Acometimento Oral no Pênfigo Vulgar. Rev Bras Otorrinolaringol. 2003;69(3):327-31.

64. Hale EK, Bystryn JC. Laryngeal and nasal involvement in pemphigus vulgaris. J Am Acad Dermatol. 2001;44:609-11.

65. Calebotta A, Cirocco A, Rodríguez MA, Sáenz AM. Pénfigo Vulgar Oral precediendo Lesiones Cutáneas. Derm Venez. 2002;40:6-10.

66. Davenport S, Chen SY, Miller AS. Pemphigus vulgaris: clinicopathologic review of 33 cases in the oral cavity. Int J Periodontics Restorative Dent. $2001 ; 21: 85-90$.

67. Scully C, Porter SR. The clinical spectrum of desquamative gengivitis. Semin Cutan Med Surg. 1997;16:308-13.

68. Mihai S, Sitaru C. Immunopathology and molecular diagnosis of autoimmune bullous diseases. J Cell Mol Med. 2007;11(3):462-81.

69. Amagai M, Komai A, Hashimoto T, Shirakata Y, Hashimoto K, Yamada $\mathrm{T}$, et al. Usefulness of enzyme-linked immunsorbent assay using recombinant desmogleins 1 and 3 for serodiagnosis of pemphigus. $\mathrm{Br} \mathrm{J}$ Dermatol. 1999;140:351-7.

70. Pulkkinen L, Choi YW, Simpson A, Montagutelli X, Sundberg J, Uitto J, et al. Loss of cell adhesion in Dsg3bal-Pas mice with homozygous 
deletion mutation (2079del14) in the desmoglein 3 gene. J Invest Dermatol. 2002;119(6):1237-43.

71. Amagai M, Karpati S, Prussick R, Klaus-Kovtun V, Stanley JR. Autoantibodies against the amino-terminal cadherin-like binding domain of pemphigus vulgaris antigen are pathogenic. J Clin Invest. 1992;90:919-26.

72. Hertl M, Riechers R. Analysis of the T cells that are potentially involved in autoantibody production in pemphigus vulgaris. J Dermatol. 1999;26:748-52.

73. Nishifuji K, Amagai M, Kuwana M, Iwasaki T, Nishikawa T. Detection of antigen-specific B cells in patients with pemphigus vulgaris by enzymelinked immunospot assay: requirement of $\mathrm{T}$ cell collaboration for autoantibody production. J Invest Dermatol. 2000;114:88-94.

74. Veldman CM, Gebhard KL, Uter W, Wassmuth R, Grötzinger J, Schultz E, et al. T Cell Recognition of Desmoglein 3 Peptides in Patients with Pemphigus Vulgaris and Healthy Individuals. J Immunol. 2004;172:3883-92.

75. Thorsby E. Invited anniversary review: HLA associated diseases. Hum Immunol. 1997;53:1-11.

76. Flavell RA, Hafler DA. Autoimmunity. Curr Opin Immunol. 1999;11:635-707.

77. Fernandes APM, Maciel LMZ, Foss MC, Donadi EA. Como entender a associação entre o sistema HLA e as Doenças Auto-imunes endócrinas. Arq Bras Endocrinol Metab. 2003;47(5):601-11.

78. Attia J, Ioannidis JPA, Thakkinstian A, McEvoy M, Scott RJ, Minelli C, et al. How to Use an Article About Genetic Association. A: Background Concepts. JAMA. 2009;301(1):74-81.

79. Klein J, Sato A. Advances in Immunology: The HLA System (Second of Two Parts). NEJM. 2000;343(11):5.

80. Wucherpfennig KW, Yu B, Bhol K, Monos DS, Argyris E, Karr RW, et al. Structural basis for major histocompatibility complex (MHC)-linked 
susceptibility to autoimmunity: Charged residues of a single MHC binding pocket confer selective presentation of self-peptides in pemphigus vulgaris. Proc Natl Acad Sci USA. 1995;92:11935-9.

81. Lin MS, Swartz SJ, Lopez A, Ding X, Fernandez-Vina MA, Stastny P, et al. Development and characterization of desmoglein-3 specific T cells from patients with pemphigus vulgaris. J Clin Invest. 1997;99:31.

82. Ribeiro D. O povo brasileiro: a formação e o sentido do Brasil. 2a ed. São Paulo: Companhia das Letras; 1995.

83. Mörner M. Race Mixture in the History of Latin America. Boston: Little, Brown \& Company; 1967.

84. Klein HS. As origens africanas dos escravos brasileiros. In: Pena SDJ, editor. Homo brasilis. 2a ed. Ribeirão Preto: FUNPEC; 2002. p. 196.

85. IBGE. Pesquisa Nacional por Amostra de Domicílios - Síntese de Indicadores 2003: Notas técnicas. 2004.

86. Anhalt G, Kim S, Stanley JR, Korman NJ, Jabs DA, Kory M, et al. Paraneoplastic Pemphigus: An Autoimune Mucocutaneous Disease Associated with Neoplasia. N Engl J Med. 1990;323(25):1729-35.

87. Camisa C, Helm TN. Paraneoplastic pemphigus is a distinct neoplasiainduced autoimmune disease. Arch Dermatol. 1993;129:883-6.

88. INCA Ministério da Saúde. Registro Nacional de Doadores de Medula Óssea (REDOME). [acessado em 16 de agosto de 2009]; Disponível em: http://www.inca.gov.br/conteudo_view.asp?ID=677

89. Olerup O, Zetterquist H. HLA-DR typing by PCR amplification with sequence-specific primers (PCR-SSP) in 2 hours: An alternative to serological DR typing in clinical practice including donor-recipient matching in cadaveric transplantation. Tissue Antigens. 1992;39(5):22535.

90. Pei R, Lee J-H, Shih N-J, Chen M, Terasaki PI. Single Human Leukocyte Antigen flow cytometry beads for accurate identification of Human Leukocyte Antigen antibody specificities. Transplantation. 2003;75:439. 
91. Cesbron-Gautier A, Simon P, Achard L, Cury S, Follea G, Bignon J-D. Technologie Luminex : application aux typages HLA par biologie moléculaire (PCR-SSO) et à I'identification des anticorps anti-HLA. Ann Biol Clin. 2004;62:93-8.

92. Marsh SGE, Albert ED, Bodmer WF, Bontrop RE, Dupont B, Erlich HA, et al. Nomenclature for factors of the HLA system, 2010. Tissue Antigens. 2010;75:291-455.

93. NMDP. HLA Resources: Allele Code List in Alphabetical Order. 2010 [acessado em 08.06.2010]; Disponível em: http://bioinformatics.nmdp.org/HLA/Allele_Codes/Allele_Code_Lists/Alp habetical Order/index.html

94. Imanishi T, Akaza T, Kimura A. Estimation of allele and haplotype frequencies for HLA and complement loci. In: Tsuji K, Aizawa M, Sasazuki T, editores. HLA 1991. New York: Oxford University Press; 1992. p. 76-9.

95. Nyholt DR. Genetic case-control association studies - correcting for multiple testing. Hum Genet. 2001;109(5):564-5.

96. Weller JI, Song JZ, Heyen DW, Lewin HA, Ron M. A New Approach to the Problem of Multiple Comparisons in the Genetic Dissection of Complex Traits. Genetics. 1998;150:1699-706.

97. Benjamini Y, Drai D, Elmer G, Kafkafi N, Golani I. Controlling the false discovery rate in behavior genetics research. Behav Brain Res. $2001 ; 125: 279-84$.

98. Woolf B. On estimating the relation between blood group and disease. Ann Hum Genet. 1955;19:251-3.

99. Haldane JBS. The estimation and significance of the logarithm of a ratio of frequencies. Ann Hum Genet. 1956;1956(20):309-11.

100. Excoffier L, Laval G, Schneider S. Arlequin (version 3.0): An integrated software package for population genetics data analysis. Evolutionary Bioinformatics. 2005;1:47-50. 
101. Herbst A, Bystryn J-C. Patterns of remission in pemphigus vulgaris. J Am Acad Dermatol. 2000;42(3):422-7.

102. Cardon LR, Palmer LJ. Population stratification and spurious allelic association. Lancet. 2003;361:598-604.

103. Whitacre CC. Sex differences in autoimmune disease. Nat Immunol. $2001 ; 2(9): 777-80$.

104. Wacholder S, Rothman N, Caporaso N. Population stratification in epidemiologic studies of common genetic variants and cancer: quantification of bias. J Natl Cancer Inst. 2000;92:1151-8.

105. Wucherpfennig KW, Strominger JL. Selective binding of self peptides of disease-associated major histocompatibility complex (MHC) molecules: a mechanism for MHC-linked susceptibility to human autoimmune diseases. J Exp Med. 1995;181:1597-601.

106. Veldman C, Stauber A, Wassmuth R, Uter W, Schuler G, Hertl M. Dichotomy of Autoreactive Th1 and Th2 Cell Responses to Desmoglein 3 in Patients with Pemphigus Vulgaris (PV) and Healthy Carriers of PVAssociated HLA Class II Alleles. J Immunol. 2003;170:635-42.

107. Morgun A, Godcalves-Primo A, Shulzhenko N, Rampim GF, Mine KL, Gerbase-Delima M. HLA-DQB1 and -DRB1 Alleles, Cytokine Polymorphisms and KIR Gene Frequencies in a Population (Caucasian) from South East Brazil. Hum Immunol. 2004;65(9):879 -82.

108. Temin J, Marques GD, Morgun A, Shulzhenko N, Rampim GF, GerbaseDeLima M. HLA-DQB1 and -DRB1 alleles and cytokine polymorphisms in a Mulatto population from South East Brazil. Hum Immunol. 2004;65(9):882-5.

109. Louzada-Junior P, Smith AG, Hansen JA, Donadi EA. HLA-DRB1 and DQB1 alleles in the Brazilian population of the northeastern reagion of the state of São Paulo. Tissue Antigens. 2001;57:158-62.

110. Maciag PC, Schlecht NF, Souza PS, Franco EL, Villa LL, Petzl-Erler ML. HLA-DQA1, -DQB1 and -DRB1 Alleles in a Population from Northeast Brazil. Hum Immunol. 2004;65:876-8. 
111. Tsuneto LT, Probst CM, Hutz MH, Salzano FM, Rodriguez-Delfin LA, Zago MA, et al. HLA class II diversity in seven Amerindian populations. Clues about the origins of the Ache. Tissue Antigens. 2003;62:512-26.

112. Trachtenberg EA, Keyeux G, Bernal J, Noble JA, Erlich HA. Results of Expedicion Humana: II. Analysis of HLA class II alleles in three African American populations from Colombia using the PCR/SSOP: identification of a novel DQB ${ }^{*} 02\left({ }^{*} 0203\right)$ allele. Tissue Antigens. 1996;48(3):192-8.

113. Trachtenberg EA, Keyeux G, Bernal JE, Rhodas MC, Erlich HA. Results of Expedicion Humana: I. Analysis of HLA class II (DRB1-DQA1-DQB1DPB1) alleles and DR-DQ haplotypes in nine Amerindian populations from Colombia. Tissue Antigens. 1996;48(3):174-81.

114. Middleton D, Menchaca L, Rood H, Komerofsky R. New Allele Frequency Database: http://www.allelefrequencies.net. Tissue Antigens. 2003;61:403-7.

115. Pablo R, García-Pacheco JM, Vilches C, Moreno ME, Sanz L, Rementería MC, et al. HLA class I and class II allele distribution in the Bubi population from the island of Bioko (Equatorial Guinea). Tissue Antigens. 1997;50:593-601.

116. Testi M, Mariani M. HLA A-B-Cw-DPB1-DQA1-DQB1- and DRB1 allele frequencies in a population from Rome Italy. Hum Immunol. 2004;65:987-91.

117. Johansson A, Ingman M, Mack SJ, Erlich H, Gyllensten U. Genetic origin of the Swedish Sami inferred from HLA class I and class II allele frequencies. Eur J Hum Genet. 2008;16:1341-9.

118. Arnett FC, Gourh P, Shete S, Ahn CW, Honey RE, Agarwal SK, et al. Extended report: Major histocompatibility complex (MHC) class II alleles, haplotypes and epitopes which confer susceptibility or protection in systemic sclerosis: analyses in 1300 Caucasian, AfricanAmerican and Hispanic cases and 1000 controls Ann Rheum Dis. 2010;69:822-7. 
119. Li Y, Ni R, Song W, Shao W, Shrestha S, Ahmad S, et al. Clear and independent associations of several HLA-DRB1 alleles with diferential antibody responses to hepatitis B vaccination in youth. Hum Genet. 2009;126:685-96.

120. Austin PC, Mamdani MM, Juurlink DN, Hux JE. Testing multiple statistical hypotheses resulted in spurious associations: a study of astrological signs and health. J Clin Epidemiol. 2006;59:964-9. 